\title{
Foraminiferal biostratigraphy of the Middle and Upper Jurassic of the Polish Lowlands: the state of the art
}

\author{
Jolanta SMOLEŃ ${ }^{1}$ and Jolanta IWAŃCZUK ${ }^{1, *}$
}

1 Polish Geological Institute - National Research Institute, Rakowiecka 4, 00-975 Warszawa, Poland

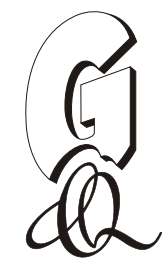

Smoleń, J., Iwańczuk, J., 2018. Foraminiferal biostratigraphy of the Middle and Upper Jurassic of the Polish Lowlands: the state of the art. Geological Quarterly, 62 (2): 257-286, doi: 10.7306/gq.1406

The foraminifera-based biostratigraphy of the Middle and Upper Jurassic of the Polish Lowlands was re-evaluated. Biostratigraphic charts providing ranges of the most important foraminiferal taxa characteristic of individual Jurassic stages are presented in relation to the currently used ammonite-based standard stratigraphic divisions. The study contains the new research on the foraminifera fauna and includes earlier results available in published and archival reports. In the Oxfordian and Lower Kimmeridgian deposits, various foraminiferal assemblages were distinguished with reference to the lithofacies in the individual parts of the Polish Basin and varying influences of the palaeogeographical provinces. Additionally, the foraminiferal zones in the Oxfordian and Lower Kimmeridgian deposits of southeastern Poland are distinguished based on detail study of foraminifers.

Key words: foraminifers, biostratigraphy, Middle and Upper Jurassic, Polish Lowlands.

\section{INTRODUCTION}

Middle and Upper Jurassic foraminifers from the Polish Lowlands have been studied for years. First data were obtained from natural outcrops in the Kraków-Wieluń Upland (e.g., Wiśniowski, 1890; Pazdro, 1954, 1958; Bielecka, 1956). Then, borehole data became available from the remaining area of the Polish Lowlands. Bielecka and Pożaryski (1954) established the first stratigraphic zonation for the Upper Jurassic of central Poland, based on microfossils. Upper Jurassic foraminiferal stratigraphy from the Chrzanów area was published by Bielecka (1960a). Subsequently, the base for establishing the foraminiferal biostratigraphy was the presence of numerous foraminiferal assemblages and their variability in the vertical profiles.

Synthetic contributions on the Jurassic of the Polish Lowlands on the basis of foraminiferal stratigraphy were published by Malinowska $(1980,1988)$ and Marek and Pajchlowa (1997). In those papers, as well as in many earlier micropalaeontological works, the stratigraphic position and the ranges of the most important foraminiferal taxa was presented against the background of various regional biostratigraphic divisions, which in many cases deviate from the European standard zonations.

\footnotetext{
* Corresponding author, e-mail: jolanta.iwanczuk@pgi.gov.pl
}

Received: July 21, 2017; accepted: January 19, 2018; first published online: April 24, 2018
The aim of the paper is to present stratigraphically important foraminiferal taxa occurring in the Middle and Upper Jurassic of the Polish Lowlands, with references to the standard ammonite divisions. In contrast to previously used divisions, the standard stages and substages applied in this publication and detailed correlation of the positions of biostratigraphic and chronostratigraphic boundaries allow using the foraminiferal data for broader, interregional correlations.

\section{MATERIAL AND METHODS}

All specimens described come from the archival collections of the PGI-NRI Geological Museum: W. Bielecka, 1954; 1960; 1981; W. Bielecka and O. Styk, 1980; 1981; J. Smoleń, 1998; 2000; 2011; 2012; 2015; J. Kopik from the Borucice1/C borehole, 1956, and collections of J. Smolen from the boreholes: Ciechocinek IG-2, 2007; Brześć Kujawski IG-1, IG-2, IG-3, 2008; Jamno IG-1, IG-2, IG-3, 2008; Grudziądz IG-1, 2011; Darżlubie IG-1, 2011; 1/1a, IG-3, IG-4; 2012; Gorzów Wielkopolski IG-1, 2014; Kętrzyn IG-1, IG2, 2014; Narol PIG-1, PIG-2, 2015 and Polik IG-1, 2016 (Fig. 1). One thousand specimens have been selected from the twenty-one collections analysed. Best-preserved 243 specimens have been photographed. SEM images have been performed in the Micro-Area Analysis Laboratory.

Stratigraphical range charts of foraminiferal taxa have been prepared with references to new data (e.g., Smoleń, 2000, 2011a, 2012a; Wierzbowski et al., 2015). Archival and unpublished micropalaeontological reports have been analysed as well. The foraminifera species list can be found in Ap- 


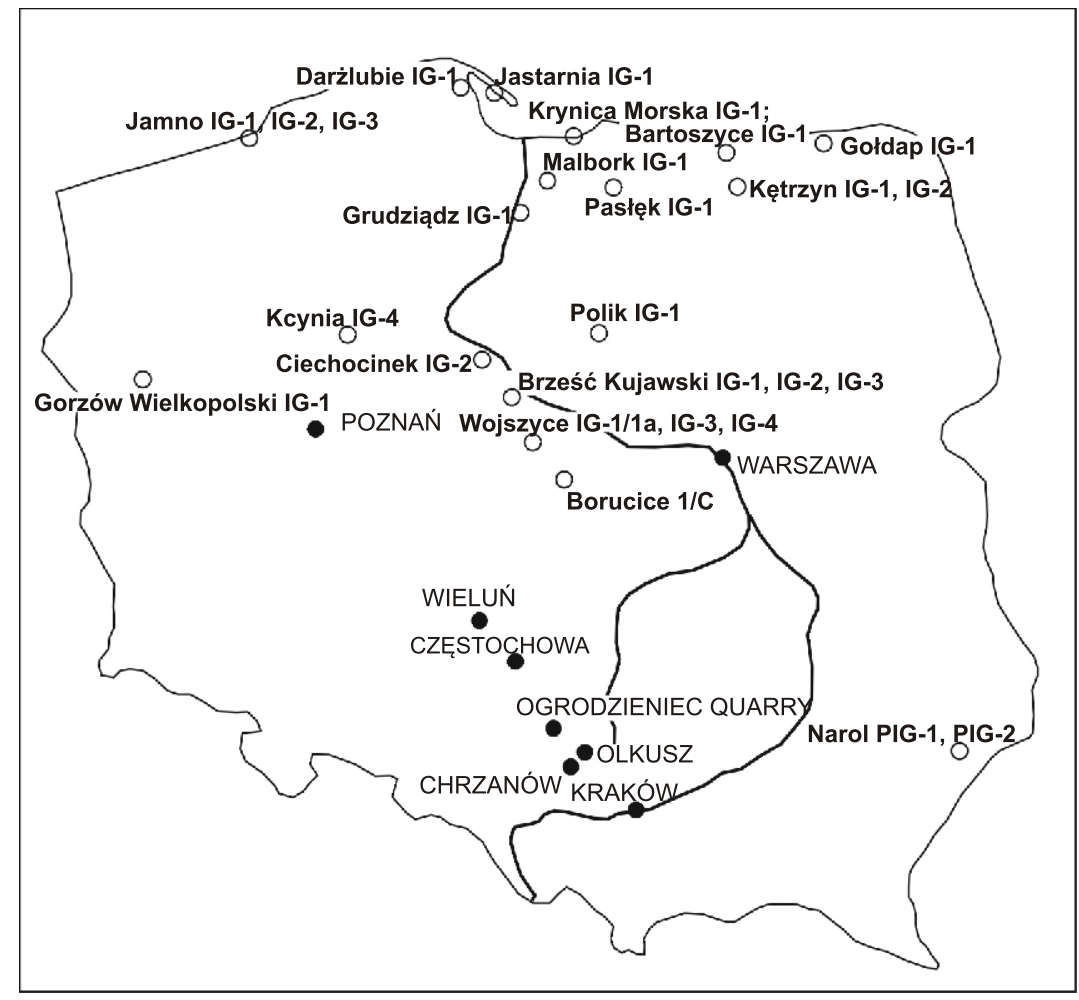

Fig. 1. Locations of boreholes that provided material used for this study

pendix $1^{*}$. The ammonite zonation applied have been based on Kopik (1998), Głowniak (2002, 2006a), Matyja and Wierzbowski (2000), Dembicz et al. (2006) and Wierzbowski et al. $(2015,2016)$.

\section{MIDDLE JURASSIC}

During the Middle Jurassic the area of Polish Lowlands was covered by an epicontinental sea (e.g., Marek and Pajchlowa, 1997). In the Aalenian, a narrow basin extended from the north-west to south-east in the present-day territory of Poland. The later transgressive impulses were the result of connections with the Tethys Ocean. The strong marine transgression covered almost the entire Polish Lowlands at the end of the Bathonian and towards the end of the Callovian. Middle Jurassic deposits developed as a sequence consisting of sandstones and clayey rocks, with carbonate-clastic facies dominant in the Upper Callovian. Middle Jurassic deposits of extra-Carpathian Poland contain diverse and multi-species foraminiferal assemblages that were subject to many micropalaeontological and biostratigraphic studies. These studies resulted in the identification of the characteristic foraminifera species and assemblages of the individual Middle Jurassic chronostratigraphic units. Composite charts of the ranges of important foraminifera species, correlated with the ammonite stratigraphy, are presented by Bielecka et al. (1980), Dayczak-Calikowska and Marcinkiewicz (1997), and Kopik and Marcinkiewicz (1997). In these publications, like in many other published and archival works, a subdivision into ammonite zones (providing regional ammonite zones based on local ranges of ammonites) was used for the Middle Jurassic deposits of the Polish Lowlands (Dayczak-Calikowska and Kopik, 1973), based on the scheme by Różycki (1953). The Submediterranean standard zonal scheme (with minor modification) was applied first by Kopik (1998: table 3) who correlated it with local biostratigraphic schemes used previously in Poland. He correlated the Lower Kuiavian and large part of the Middle Kuiavian with the Upper Bajocian standard substage, and the uppermost part of the Middle Kuiavian (Schloenbachii Zone) and the Upper Kuiavian with the Bathonian standard stage (Fig. 2).

\section{AALENIAN}

The Lower Aalenian is represented in the Polish Lowlands by sandy-muddy deposits (e.g., Dayczak-Calikowska, 1997; Feldman-Olszewska, 1997). Marine facies of central Poland contain scarce agglutinated foraminifers. The Upper Aalenian is better documented by foraminifera fauna by Bielecka and Styk (1981a) and Kopik (1956). In clay-muddy deposits, starting from the Murchisonae Zone, foraminiferal assemblages are represented by abundant agglutinated foraminifera and few foraminifer specimens with calcareous tests, which appear for the first time in the Aalenian deposits of the Polish Lowlands. The statigraphically important Upper Aalenian species include the following taxa: Reinholdella dreheri (Bartenstein) (Fig. 3C1, C2), Verneuilinoides liasina (Terquem et Berthelin) (Fig. 3B), Ammodiscus glumaceus Gerke et Sossipatrova (Fig. 3A), Astacolus varians rectus Franke, A. reticulatus (Schwager) (Fig. 3E) Trochamminiodes proteus (Karrer) (Fig. 3D), Lagenammina difflugiformis (Brady) (Fig. 3H) and Recurvoides trochamminiforme Höglund (Fig. 3G), Trochammina canningensis Tappan (Fig. 3l, J) and Haplophragmopides complanatus Mjatliuk (Fig. $3 \mathrm{~L}$ ) which are rarely found from Discites to Humpresianum zones (Fig. 4).

\footnotetext{
* Supplementary data associated with this article can be found, in the online version, at doi: 10.7306/gq.1406
} 


\begin{tabular}{|c|c|c|c|c|c|c|c|c|c|c|}
\hline \multicolumn{4}{|c|}{$\begin{array}{c}\text { Standard ammonite zones } \\
\text { and subzones }\end{array}$} & \multicolumn{4}{|c|}{$\begin{array}{l}\text { Ammonite zones } \\
\text { and subzones } \\
\text { (Kopik, 1998) }\end{array}$} & \multicolumn{3}{|c|}{$\begin{array}{c}\text { Ammonite zones } \\
\text { and subzones } \\
\text { (Dayczak-Calikowska } \\
\text { and Kopik, 1973) }\end{array}$} \\
\hline \multicolumn{2}{|c|}{ OXF. } & \multicolumn{2}{|c|}{ Mariae } & \multicolumn{2}{|c|}{ OXF. } & \multicolumn{2}{|c|}{ Mariae } & \multirow{2}{*}{\multicolumn{2}{|c|}{ OXF. }} & Mariae \\
\hline \multirow{7}{*}{ 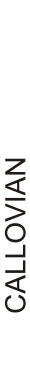 } & & \multicolumn{2}{|c|}{ Lamberti } & \multirow{7}{*}{ 这 } & \multirow{4}{*}{ 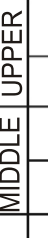 } & Lamb & & & & Lamberti \\
\hline & & Athlet & & & & Athlet & & \multirow{6}{*}{ 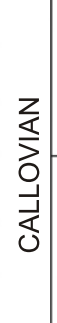 } & \multirow{3}{*}{$\begin{array}{l}\frac{r}{w} \\
\frac{\alpha}{\Delta} \\
\frac{\partial}{\partial}\end{array}$} & Duncani \\
\hline & \multirow{5}{*}{ 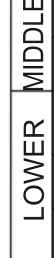 } & \multicolumn{2}{|c|}{ Coronatum } & & & \multicolumn{2}{|c|}{ Coronatum } & & & Pollux \\
\hline & & \multicolumn{2}{|c|}{ Jason } & & & \multicolumn{2}{|c|}{ Jason } & & & Jason \\
\hline & & \multicolumn{2}{|c|}{ Calloviense } & & $\Upsilon$ & \multirow{2}{*}{ 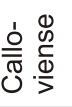 } & Calloviense & & \multirow{3}{*}{ 品 } & Collavionce \\
\hline & & Koeni & & & 岁 & & Koenigi & & & Lativinetioe \\
\hline & & Herve & & & & Herve & & & & Typicus \\
\hline & $\alpha$ & Discus & & & $\propto$ & Discu & & & $\alpha$ & Discus \\
\hline & $\begin{array}{l}\omega \\
0\end{array}$ & & & & 㟔 & & Orbis & $z$ & $\frac{\omega}{a}$ & Paradoxus \\
\hline & & Netiog & (Statumi & & & ठั & Heterocostatus & $\S$ & כ & Heterocostatus \\
\hline & & Brem & & & & Brem & & 눝 & س & Bremeri \\
\hline 这 & Ш & Morris & & $\frac{1}{3}$ & 山 & Morris & & $\infty$ & $\overrightarrow{0}$ & \\
\hline$\stackrel{I}{E}$ & $\bar{\Sigma}$ & Subce & tractus & I & $\bar{\Sigma}$ & Subce & intractus & & & \\
\hline (ิ) & & & & $\infty$ & & & & & రิ & Procerites spp. \\
\hline & & Tenuip & satus & & & Tenui & licatus & & & Tenuiplicatus \\
\hline & 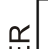 & & Yeovilensis & & $\frac{⿱}{w}$ & Yeovil & ensis & & $\frac{r}{w}$ & Yeovilensis \\
\hline & 岁 & 뮤 & Macrescens & & o & Macre & scens & & $\bar{n}$ & Compressa \\
\hline & & $\stackrel{0}{N}$ & Converaenc & & & & avergens & & & Ferruginea \\
\hline & & & & & & & & ऐे & & Schloenbachi \\
\hline & & "ב & Bomfordi & & & Parkir & soni & $\vec{z}$ & $\vec{a}$ & Parkinconi \\
\hline & & $\stackrel{\mathscr{n}}{\frac{\mathscr{L}}{x}}$ & Densicostata & & & & & z⿺ & $\bar{\Sigma}$ & \\
\hline & & $\frac{10}{\pi}$ & Acris & & & Acris & & $\overline{\mathrm{O}}$ & & Subarietis \\
\hline & 品 & $\underset{\widetilde{T}}{\complement}$ & Tetragona & & 岀 & $\stackrel{\mathbb{1}}{=}$ & Tetragona & 造 & & Tetragona \\
\hline & $\overline{5}$ & 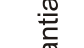 & Trauthi & & 5 & $\stackrel{\frac{N}{2}}{\frac{1}{\sigma}}$ & Trauthi & $\stackrel{\frac{n}{w}}{\underline{\sim}}$ & $\frac{\mathscr{r}}{w}$ & $\rho_{0}$ \\
\hline$z$ & & 苂 & Dichotoma & $z$ & & 心 & Dichotoma & $\bar{\Omega}$ & రิ & Lararitiania \\
\hline Oু & & & bfurcatum & ర్ & & Subfu & catum & & & Subfurcatum \\
\hline & & & Blagdeni & & & $\stackrel{\dot{\phi}}{\underline{\underline{\sigma}}} \varepsilon$ & Blagdeni & & & Blagdeni \\
\hline & & 흘 & Humphriesianum & & & 들 & Humphriesianum & & & \\
\hline & $\underline{\sim}$ & 곧 & Romani & & $\stackrel{\sim}{\varpi}$ & 고 & Romani & $\frac{\pi}{0}$ & & mumpintestarium \\
\hline & 3 & Sauze & & & ర్త & Sauze & & 这 & & Sauzei \\
\hline & & Laevil & cula & & & Laevil & scula & 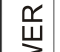 & & \\
\hline & & Discite & & & & Discit & & & & \\
\hline$z$ & $\frac{r}{w}$ & Conce & & & 虽 & Conce & vum & $z$ & 品 & Mumbrong \\
\hline 岃 & $\frac{1}{2}$ & Murch & onae & $\sum_{i=1}^{2}$ & 㟧 & Murch & isonae & 岂 & $\frac{10}{5}$ & 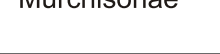 \\
\hline 这 & 3े| & Opalir & & 岁 & בें & Opalir & um & 这 & ذิ & Opalinum \\
\hline
\end{tabular}

Fig. 2. Correlation of the zonal schemes

(after Kopik, 1998, modified by Matyja and Wierzbowski, 2000) 


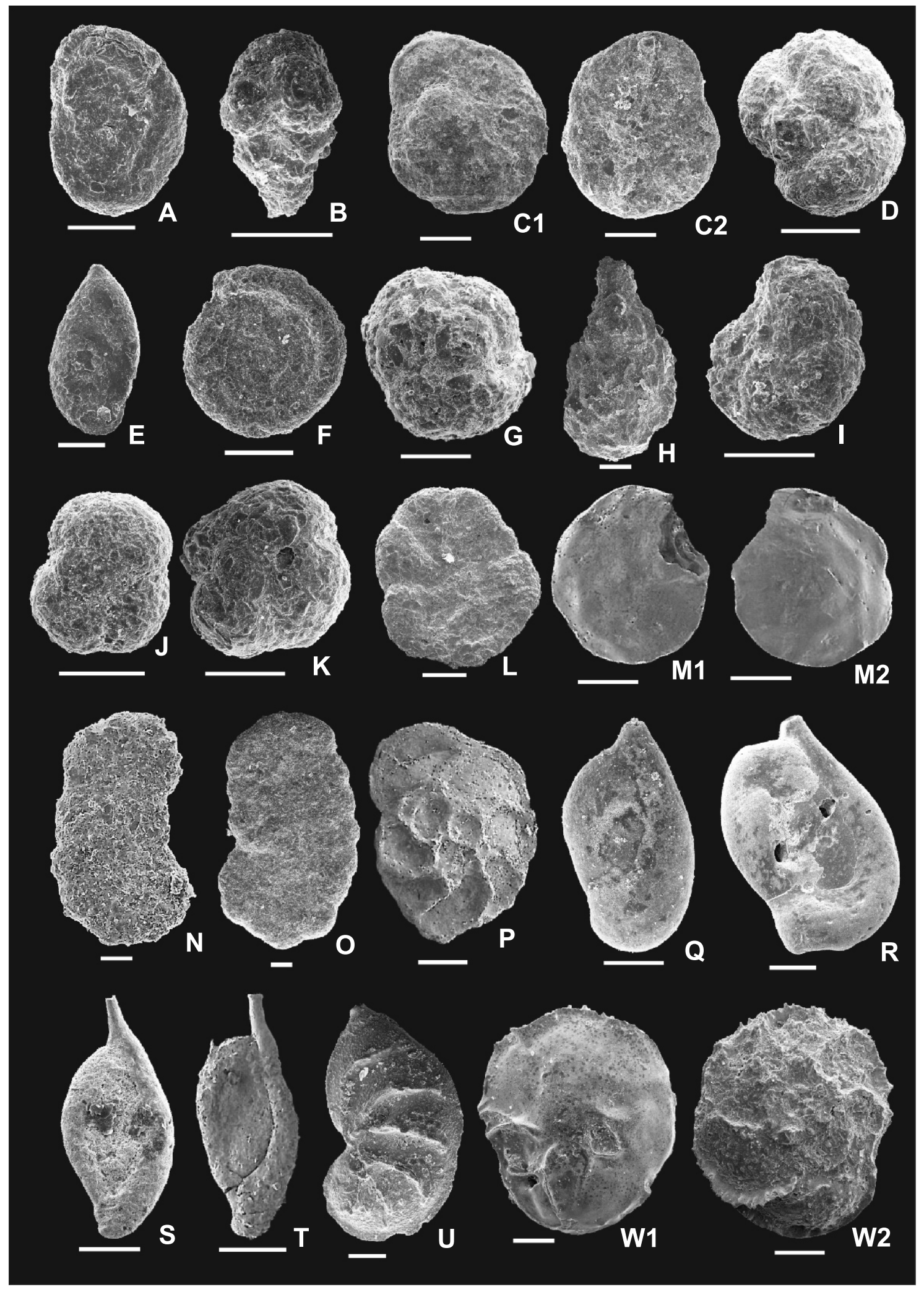

Fig. 3. Foraminifers from the Aalenian-Lower Bajocian (A-H) and Upper Bajocian (I-W2) deposits of the Polish Lowlands

A - Ammodiscus glumaceus (collection of Smoleń from the Brześć Kujawski IG-1, IG-2 and IG-3 boreholes, 2008); B - Verneuilinoides liasina (collection of Kopik, 1956); C1 - Reinholdella dreheri, dorsal side (collection of Kopik, 1956); C2 - Reinholdella dreheri, ventral side (collection of Kopik, 1956); D - Trochamminoides proteus (collection of Smoleń from the Brześć Kujawski IG-1, IG-2 and IG-3 boreholes, 2008); E - Astacolus reticulatus (collection of Kopik, 1956); F - Ammodiscus orbis (collection of Smoleń from the Brześć Kujawski IG-1, IG-2 and IG-3 boreholes, 2008); G - Recurvoides trochamminiforme (collection of Kopik, 1956); H - Lagenammina difflugiformis (collection of Kopik, 1956); I, J - Trochammina canningensis (collection of Kopik, 1956); K - Recurvoides trochamminiforme (collection of Kopik, 1956); L - Haplophragmoides complanatus (collection of Smoleń, 2011); M1 - Epistomina nuda, ventral side (collection of Smoleń, 2011); M2 Epistomina nuda, dorsal side (collection of Smoleń, 2011); N - Ammopalmula infrajurensis (collection of Kopik, 1956); O - Ammopalmula infrajurensis (collection of Smoleń from the Wojszyce IG-1/1a, IG-3 and IG-4 boreholes, 2012); P - Epistomina costifera (collection of Smoleń from the Brześć Kujawski IG-1, IG-2 and IG-3 boreholes, 2008); Q, R - Ophthalmidium carinatum terquemi (collection of Smoleń, 2011); S, T - Ophthalmidium carinatum agglutinans (collection of Smoleń, 2011); U - Lenticulina (Astacolus) interrumpa (collection of Bielecka and Styk, 1980); W1 - Garantella ornata, ventral side (collection of Bielecka and Styk, 1980); W2 - Garantella ornata, dorsal side (collection of Bielecka and Styk, 1980); scale bars - $100 \mu \mathrm{m}$ 


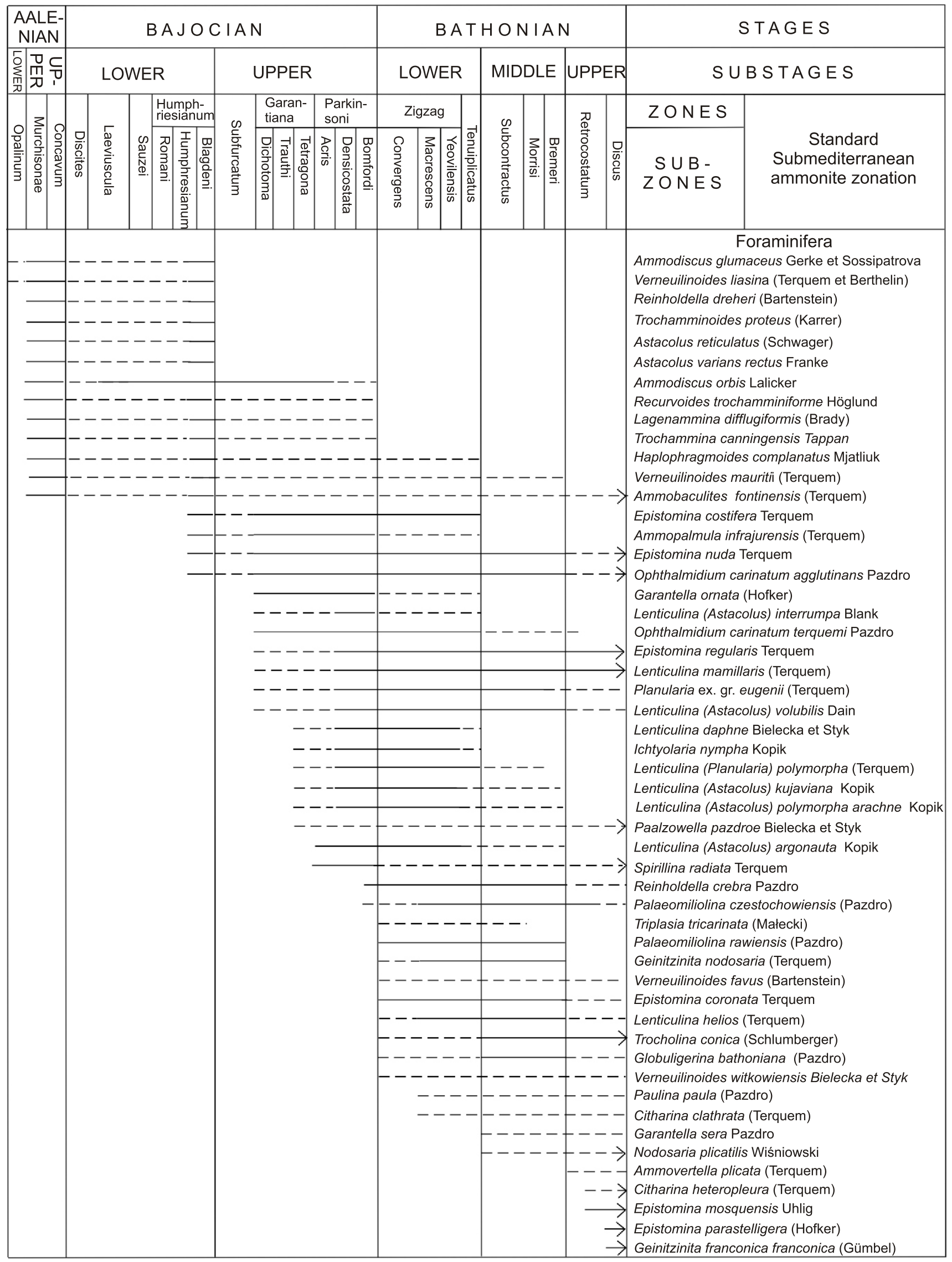

Fig. 4. Stratigraphic range charts of foraminifera species from the Aalenian and Bathonian deposits of the Polish Lowlands, ammonite zonation as used by Kopik (1998), Matyja and Wierzbowski (2000), Barski et al. (2004) and Dembicz et al. (2006) 


\section{BAJOCIAN}

Lower Bajocian shallow-marine deposits, represented mainly by sandstones, mudstones and rare claystones, contain poor foraminiferal assemblages. In central Poland, there are few taxa, generally the same as those found in the Upper Aalenian (see Fig. 4). Detailed investigations of the Lower Bajocian sandy deposits (the Kościeliskie Beds), conducted between Czestochowa and Zawiercie, revealed also scarce microfauna (Kopik, 1998). Their lower part (the Kościeliskie sandstones) contains single agglutinated foraminifers. Larger foraminiferal assemblages have been found in the uppermost Lower Bajocian - Humphriesianum Zone, Blagdeni Subzone; Kopik, 1998).

Most of the foraminifera species, which continue from the Aalenian in the Polish Lowlands, have their last occurrences at the end of the Lower Bajocian. This is associated with a regressive event that started and continued during the early Late Bajocian (Dayczak-Calikowska, 1980). The lowermost Upper Bajocian (Subfurcatum Zone) of central Poland, represented by muddy-sandy facies, contains few foraminifera species. These include predominantly agglutinated and infrequent calcareous foraminifera, e.g.: Ophthalmidium carinatum agglutinans Pazdro, Epistomina nuda Terquem and E. costifera Terquem (Fig. 4; Bielecka and Styk, 1981a). Subsequent studies conducted in south-central Poland between Częstochowa and Zawiercie did not confirm the presence of Subfurcatum Zone deposits (Kopik, 1998).

Deposits of the Upper Bajocian Garantiana Zone record an onset of marine transgression and the sedimentary basin expansion. Throughout the Late Bajocian, the clay-muddy facies dominate a vast area of central Poland. A complex of claystones, mudstones and sandstones with siderites, referred to as the Częstochowa ore-bearing clays, was deposited in the Częstochowa-Zawiercie region (e.g., Leonowicz, 2013a, b, 2015). The Upper Bajocian deposits contain large foraminiferal assemblages, abundant in terms of the number of both species and specimens, described in papers by Pazdro (1954, 1958, 1969a), Bielecka and Styk (1969a, b, 1981a), Kopik (1956, 1969) and Smoleń (2008a, 2011a, 2012b, 2014a). In central Poland, the foraminifera fauna appears again in the Garantiana Zone, in which calcareous foraminifera become definitely predominant. The largest foraminiferal assemblages are known from the Parkinsoni Zone (equivalent of the Acris and Parkinsoni zones sensu Kopik, 1998). In the Częstochowa-Zawiercie region (south-central Poland), the first foraminifera appear later in the Parkinsoni Zone and the largest foraminiferal assemblages occur in the upper part of this zone (in the Acris and Parkinsoni zones sensu Kopik, 1998; Fig. 4).

The study of Kopik (1998) has also shown that some taxa such as Reinholdella crebra Pazdro and Palaeomiliolina czestochowiensis (Pazdro) (Fig. 4) known in central Poland only from the Bathonian onwards have their first occurrences in the uppermost Bajocian (Parkinsoni Zone sensu Kopik, 1998) in the Częstochowa region.

The analysis of studies carried out so far shows that diagnostic species in the Upper Bajocian deposits include: Epistomina nuda Terquem (Fig. 3M1, M2), E. costifera Terquem (Fig. 3P), E. regularis Terquem (Fig. 5A1, A2), Ammopalmula infrajurensis (Terquem) (Fig. 3N, O, Garantella ornata (Hofker) (Fig. 3W1, W2), Ophthalmidium carinatum terquemi Pazdro (Fig. 3Q, R), O. carinatum agglutinans Pazdro (Fig. 3S, T), Lenticulina (Astacolus) interrumpa Blank (Fig. 3U), L. (A.) volubilis Dain (Fig. 5C), L. (A.) kujaviana Kopik (Fig. 5F), L. (A.) argonauta (Kopik), L. (A.) polymorpha arachne Kopik (Fig. 5I, J), L. (Planularia) polymorpha (Terquem) (Fig. 5H), L. daphne
Bielecka et Styk (Fig. 5E), Ichtyolaria nympha Kopik (Fig. 5G), L. mamillaris (Terquem) (Fig. 5B) and Planularia ex gr. eugenii (Terquem) (Fig. 5D). Most of the foraminifera species, which have their first occurrences in the Upper Bajocian, range through the Lower Bathonian, or some through the Middle or even Upper Bathonian.

\section{BATHONIAN}

Over most of the Polish Lowlands, the Bathonian succession consists of clastic deposits represented by muddy-sandy and muddy-clayey facies with sideritic coquina layers, passing into sandstone facies. Such sedimentation type persisted until the end of the Bathonian in much of the Polish Lowlands, mainly in central and northwestern Poland. In south-central Poland (the region between Częstochowa and Zawiercie), clayey, muddy and sandy deposits with siderites were accumulated, referred to as the Częstochowa ore-bearing clay formation (Gedl and Kaim, 2012). The final stage of the deposition of these clays started in the Late Bathonian Retrocostarum Zone (Heterocostatus Subzone of the Orbis Zone sensu Kopik, 1998; Fig. 2). This zone contains also rare mudstones which are replaced by oolitic limestones (called the Częstochowa oolite). In many areas of the Kraków-Częstochowa Upland, the uppermost Upper Bathonian (Discus Zone) refers to an erosional hiatus (Kopik, 1998).

Like those of the Upper Bajocian, the Bathonian foraminifera form multi-species microfaunal associations. They have been well investigated and described from many boreholes, mainly in central and NW Poland (Bielecka and Styk, 1969a, b, 1981b; Kopik, 1969; Smoleń, 2007, 2008b, 2011b, c, 2012b, 2014a, b). The oldest contributions on Bathonian foraminifera concerned ore-bearing clays from the Kraków-Wieluń Upland (Pazdro, 1954, 1959, 1960, 1967, 1969a, b; Małecki, 1971; Garbowska et al., 1978). In the area between Częstochowa and Zawiercie, Kopik (1998) distinguished foraminiferal assemblages characteristic of the individual Bathonian substages.

Based on correlation with standard ammonite zones (after Maryja and Wierzbowski, 2000, 2003), the largest foraminiferal assemblages have been documented in strata containing continuous concretionary siderite horizons. Large and taxonomically diverse foraminiferal assemblages are found in the Lower Bathonian deposits of the Convergens and Macrescens subzones of the Zigzag Zone (Smoleń, 2011a). In the Middle Bathonian, such associations are present mainly in the Subcontractus and Morissi zones (Smoleń, 2004, 2006, 2012a).

Analysis of the above-mentioned previous studies has shown that the Lower Bathonian deposits contain most of the species that are found in the uppermost Upper Bajocian. The following species terminate their stratigraphic ranges in the Lower Bathonian (Tenuiplicatus Zone; Fig. 4): Ammopalmula infrajurensis (Terquem), Garantella ornata (Hofker), Lenticulina (A.) interrumpa Blank, L. daphne Bielecka and Styk, Epistomina costifera Terquem and Ichtyolaria nympha Kopik. There is also the upper limit of the continuous range of Ophthalmudium carinatum terquemi Pazdro, and an increase in the quantitative contribution of $O$. carinatum agglutinans Pazdro, Epistomina regularis Terquem, E. nuda Terquem, Palaeomiliolina czestochowiensis (Pazdro), Planularia ex gr. eugenii (Terquem) and Lenticulina (A.) volubilis Dain. The new species, that have their first occurrences in the Lower Bathonian (Fig. 4), include Paulina paula Pazdro, Triplasia tricarinata (Małecki) (Fig. 5T), Verneuilinoides favus (Bartenstein) (Fig. 5S), Epistomina coronata Terquem (Fig. 5Y), Geinitzinita nodosaria 


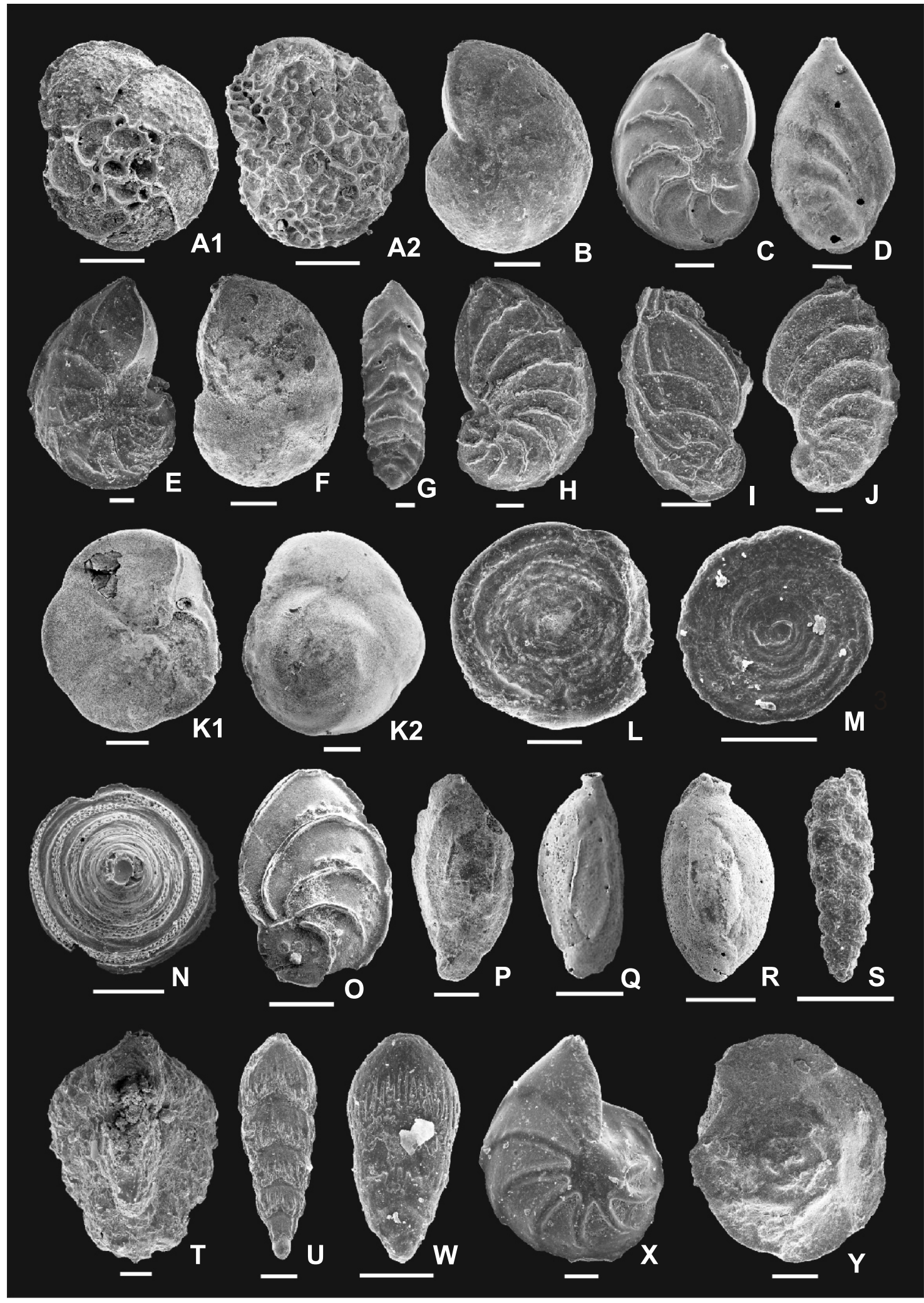

Fig. 5. Foraminifers from the Upper Bajocian (A1-J) and Lower and Middle Bathonian (K1-Y) deposits of the Polish Lowlands

A1 - Epistomina regularis, dorsal side (collection of Smoleń, 2012); A2 - Epistomina regularis, ventral side (collection of Smoleń, 2012); B Lenticulina mamillaris (collection of Smoleń, 2011); C - Lenticulina (Astacolus) volubilis (collection of Smoleń, 2012); D - Planularia ex. gr. eugenii (collection of Smoleń, 2012); E - Lenticulina daphne (collection of Bielecka and Styk, 1980); F - Lenticulina (Astacolus) kujaviana (collection of Bielecka and Styk, 1980); G - Ichtyolaria nympha (collection of Smoleń, 2011); H - Lenticulina (Planularia) polymorpha (collection of Bielecka and Styk, 1981); I, J - Lenticulina (Astacolus) polymorpha arachne (collection of Smoleń from the Polik IG-1 borehole, 2016); K1 - Reinholdella crebra, ventral side (collection of Smoleń from the Gorzów Wielkopolski IG-1 borehole, 2014); K2 - Reinholdella crebra, dorsal side (collection of Smoleń from the Gorzów Wielkopolski IG-1 borehole, 2014); L, M - Spirillina radiata (collection of Smoleń, 2012); N - Paalzowella pazdroe (collection of Smoleń, 201); 0 - Lenticulina (Astacolus) argonauta (collection of Smoleń, 2011); P, Q Palaeomiliolina czestochowiensis (collection of Smoleń, 2012); $\mathbf{R}$ - Palaeomiliolina rawiensis (collection of Smoleń from the Jamno IG-1, IG-2 and IG-3 boreholes, 2008); S - Verneuilinoides favus (collection of Kopik, 1956); T - Triplasia tricarinata (colletion of Bielecka and Styk, 1980); U, W - Geinitzinita nodosaria (collection of Smoleń, 2012); X - Lenticulina helios (collection of Smoleń, 2012); Y - Epistomina coronata (collection of Smoleń from the Brześć Kujawski IG-1, IG-2 and IG-3 boreholes, 2008); scale bars - $100 \mu \mathrm{m}$ 
(Terquem) (Fig. 5U, W), Palaeomiliolina rawiensis (Pazdro) (Fig. 5R), and Lenticulina helios (Terquem) (Fig. 5X). As evidenced from the studies by Kopik (1998), the Lower Bathonian deposits from the area between Czestochowa and Zawiercie reveal the first occurrences of species such as Globuligerina bathoniana (Pazdro), Trocholina conica (Schlumberger) and Verneuilinoides witkowiensis Bielecka et Styk, known in the rest of the Polish Lowlands from the Middle Bathonian onwards.

Middle Bathonian deposits of the Polish Lowlands also contain multi-species foraminiferal assemblages. Many species continue from the previous zones; however, there is a change in the quantitative proportions between the individual taxa. Continual stratigraphic ranges are characteristic of the following species (Fig. 4): Palaeomiliolina czestochowiensis (Pazdro) (Fig. 5P, Q), P. rawiensis (Pazdro), Ophthalmidium carinatum agglutinans Pazdro, Epistomina nuda Terquem, E. regularis Terquem, Reinholdella crebra Pazdro (Fig. 5K1, K2), Lenticulina helios (Terquem), and Globuligerina bathoniana (Pazdro) (Fig. 6B). Other numerously occurring taxa are Lenticulina (A.) volubilis Dain, L. mamillaris (Terquem), Trocholina conica (Schlumberger) (Fig. 6A1, A2), Paalzowella pazdroe Bielecka et Styk (Fig. 5N), Lenticulina (Astacolus) argonauta Kopik (Fig. 50), Citharina clathrata (Terquem) (Fig. 6E) and Spirillina radiata Terquem (Fig. 5L, M). The new species that appear in the Middle Bathonian include Nodosaria plicatilis Wiśniowski (Fig. 6F), Garantella sera Pazdro, G. arantella aff. stellata Kaptarenko and Epistomina bireticulata (Pazdro). Many species, which also occur in the previous zones, terminate their stratigraphic ranges (Fig. 4). Besides these characteristic species, the Middle Bathonian deposits contain species with long age ranges. The most common of such taxa are: Reophax fusiformis (Williamson) (Fig. 6M), Citharina macilenta (Terquem) (Fig. 6N), C. oolithica (Schwager) (Fig. 6O), Dentalina gumbeli Hantken (Fig. 6P), Lagena globosa (Montagu) (Fig. 6L), Haplophragmoides canui Cushman (Fig. 6K) and Ammodiscus orbis Laliker (Fig. 6J).

The Upper Bathonian foraminiferal assemblages show lower taxonomical diversity, though the specimens are numerous. Basically, there are no species typical exclusively for this substage except for one new species of Ammovertella plicata (Terquem) (Figs. 4 and $6 \mathrm{H} 1, \mathrm{H} 2$ ) which is known only from the Upper Bathonian in Poland. The Upper Bathonian deposits again contain numerous specimens of the species Palaeomiliolina czestochowiensis (Pazdro), Ophthalmidium carinatum agglutinans Pazdro, Epistomina nuda Terquem, E. regularis Terquem, Trocholina conica (Schlumberger), Paalzowella pazdroe Bielecka and Styk, Lenticulina mamillaris (Terquem) and L. helios (Terquem), Paulina paula (Pazdro) (Fig. 6D), Verneuilinoides witkowiensis Bielecka and Styk (Fig. 6C) and Ammovertella plicata (Terquem) (Figs. 4 and 6H1, H2). Most foraminiferal species, which were also present in the older strata, became extinct at the end of the Bathonian. In south-central Poland (Częstochowa-Zawiercie region), most foraminiferal species have their last occurrences at the end of clay-muddy sedimentation of the Częstochowa ore-bearing clays (Kopik, 1998). In north-western Poland, where the clay-muddy sedimentation persisted for the longest time, foraminifera are fairly numerous in the uppermost Bathonian, in the Discus Zone. In this region, a few new Callovian species have their first occurrences at the end of the Discus Zone (Bielecka and Styk, 1981b). These are Epistomina mosquensis Uhlig, E. parastelligera (Hofker) and Geinitzinita franconica franconica (Gümbel).

\section{CALLOVIAN}

The Callovian/Oxfordian boundary, between the Lamberti and Mariae zones (Fig. 2), has been documented based on ammonites in the Kcynia IG-4 borehole (central Poland; Matyja and Wierzbowski, 1998) and in the Ogrodzieniec Quarry (south-central Poland; Barski et al., 2004; Dembicz et al., 2006). It is also indicated by micropalaeontological investigations carried out in NE Poland (Smoleń, 2000). As regards foraminifera, the biostratigraphic boundary between the Lamberti and Marie zones is reflected by a global change in the foraminiferal assemblages (Grigelis, 1982, 1985; Mesezhnikov et al.,1989).

In the Polish Lowlands, the beginning of the Callovian corresponds to a short marine regression. In central and northwestern Poland, sandstones, dolomitic mudstones and sandy dolomites were deposited in a shallow sea (Dayczak-Calikowska,1977, 1997). In south-central Poland, accumulation of limestones and marls with ooids and calcareous-sandy deposits dominated (Feldman-Olszewska, 1997). In the Herveyi Zone, foraminifers are extremely rare and biostratigraphically insignificant. These are the species that are known from Bathonian deposits (see Figs. 4 and 7). In the Herveyi Zone, the first appearance in Poland of the species Textularia jurassica (Gümbel) (Fig. 6S) was noticed (Bielecka and Styk, 1981b). Development of foraminiferal assemblages started in the Calloviense Zone, at the time of the onset of a marine transgression. New foraminifera species appeared, such as: Dentalina brueckmanni Mjatliuk (Fig. 6U), Lenticulina pseudocrassa Mjatliuk (Fig. 6Aa), L. catascopium (Mitjanina) (Fig. 6W, X), L. okrojanzi Mjatliuk (Fig. 8A), L. lithuanica (Brückamann) (Fig. 8L, M), L. tumida (Mjatliuk) (Fig. 8B, C), Pseudolamarckina rjasanensis (Uhlig) (Fig. 8G1, G2), Vaginulinopsis rokitae Bielecka et Styk (Fig. 6Q), Astacolus protractus (Bornemann) (Fig. 6T) and A. limnatus (Schwager) (Fig. 6Y, Z), which are accompanied by those known from the older deposits (Fig. 7). Large foraminiferal assemblages, mainly of the Middle and Upper Callovian, have been described from clastic deposits represented by muddy-clayey and muddy-marly facies in NW (Bielecka, 1965; Bielecka and Styk, 1981b) and NE Poland (Smoleń, 2000, 2011b, c, 2014b).

In the Middle Callovian, the next species have their first occurrences (see Fig. 7): Lenticulina ruesti (Wiśniowski) (Fig. 8H), L. polonica (Wiśniowski) (Fig. 8N), L. ovato acuminata (Wiśniowski) (Fig. 8T), L. quenstedti (Gümbel) (Fig. 8Aa), Planularia tricostata (Mitjanina) (Fig. 8F), Planularia tricarinella (Reuss) (Fig. 8E), Geinitzinita crassata Gerke (Fig. 8O, P), Ichtyolaria supracalloviensis (Wiśniowski) (Fig. 8I, J), Epistomina elschankaensis Mjatliuk, Planularia colligata (Brückmann) (Fig. 8D), Citharinella moelleri (Uhlig) (Fig. 8Q), C. nikitini (Uhlig) (Fig. 8R), Astacolus erucaeformis (Wiśniowski) (Fig. 8U, W), and Dorothia osowiensis Bielecka et Styk (Fig. 8K). In the whole Middle Callovian, there are also numerous specimens of Epistomina mosquensis Uhlig (Fig. 6G), Geinitzinita franconica franconica (Gümbel) (Fig. 6R), E. parastelligera (Hofker) (Fig. 6I1, I2), Nodosaria mutabilis (Fig. 8S), Astacolus folium (Wiśniowski) (Fig. 9G) and Pseudolamarckina rjasanensis (Uhlig) (Fig. 7).

The Upper Callovian foraminiferal assemblages are very large with respect to the number of both species and individuals. They contain almost all species known from the previous zones. A few new species diagnostic for the Upper Callovian appear in the Athleta Zone. These are Marginulinopsis 


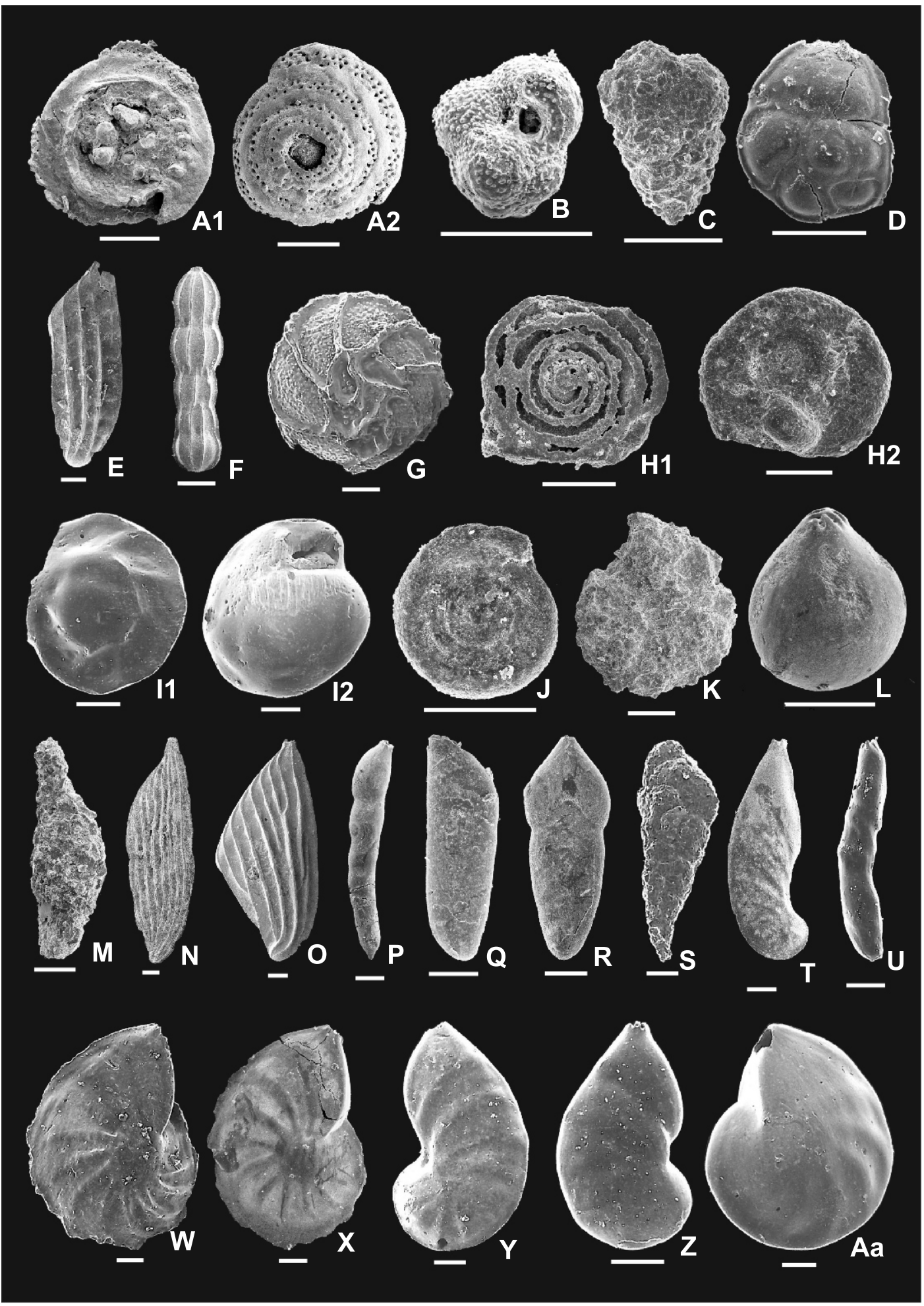

Fig. 6. Foraminifers from the Bathonian deposits (A1-P) and Callovian deposits (Q-Aa) of the Polish Lowlands

A1 - Trocholina conica, ventral side (collection of Smoleń from the Jamno IG-1, IG-2 and IG-3 boreholes, 2008); A2 - Trocholina conica, dorsal side (collection of Smoleń from the Jamno IG-1, IG-2 and IG-3 boreholes, 2008); B - Globuligerina bathoniana (collection of Smoleń, 2012); C - Verneuilinoides witkowiensis (collection of Bielecka and Styk, 1981); D - Paulina paula (collection of Bielecka and Styk, 1981); E - Citharina clathrata (collection of Bielecka 1960); F - Nodosaria plicatilis ( collection of Smoleń, 2012); G - Epistomina mosquensis (collection of Smoleń, 2000); H1 - Ammovertella plicata, ventral side (collection of Bielecka and Styk, 1980); H2 - Ammovertella plicata, dorsal side (collection of Bielecka and Styk, 1980); 11 - Epistomina parastelligera, dorsal side (collection of Smoleń, 2015); 12 - Epistomina parastelligera, ventral side (collection of Smoleń, 2015); J - Ammodiscus orbis (collection of Smoleń, 2011); K - Haplophragmoides canui (collection of Bielecka and Styk, 1980); L - Lagena globosa (collection of Smoleń, 2011); M - Reophax fusiformis (collection of Smoleń from the Gorzów Wielkopolski IG-1 borehole, 2014); N - Citharina macilenta (collection of Smoleń from the Gorzów Wielkopolski IG-1 borehole, 2014); O - Citharina oolithica (collection of Smoleń, 2011); P - Dentalina gumbeli (collection of Smoleń from the Gorzów Wielkopolski IG-1 borehole, 2014); Q - Vaginulinopsis rokitae (collection of Bielecka and Styk, 1981); $\mathbf{R}$ - Geinitzinita franconica franconica (collection of Bielecka and Styk, 1981); S - Textularia jurassica (collection of Smoleń, 1998); T - Astacolus protractus (collection of Smoleń from the Jamno IG1, IG2 and IG3 boreholes, 2008); U - Dentalina brueckmanni (collection of Smoleń, 2000); W, X-Lenticulina catascopium (collection of Smoleń, 2000); Y, Z - Astacolus limnatus (collection of Smoleń, 2000); Aa - Lenticulina pseudocrassa (collection of Smoleń, 2000); scale bars $-100 \mu \mathrm{m}$ 


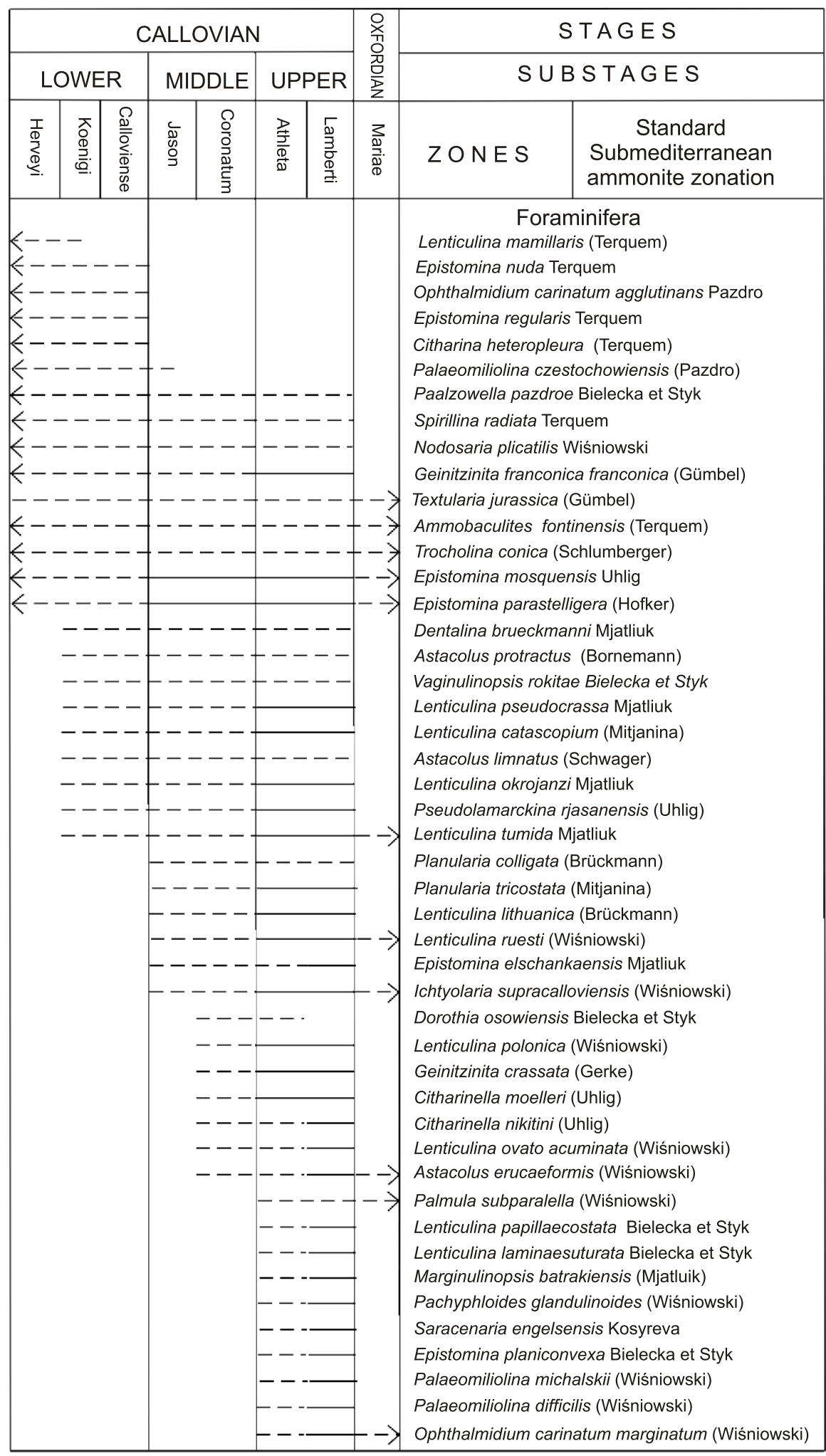

Fig. 7. Stratigraphic range charts of foraminifera species from the Callovian deposits of the Polish Lowlands, ammonite zonation as used by Kopik (1998, modfied), Barski et al. (2004) and Dembicz et al. (2006) 


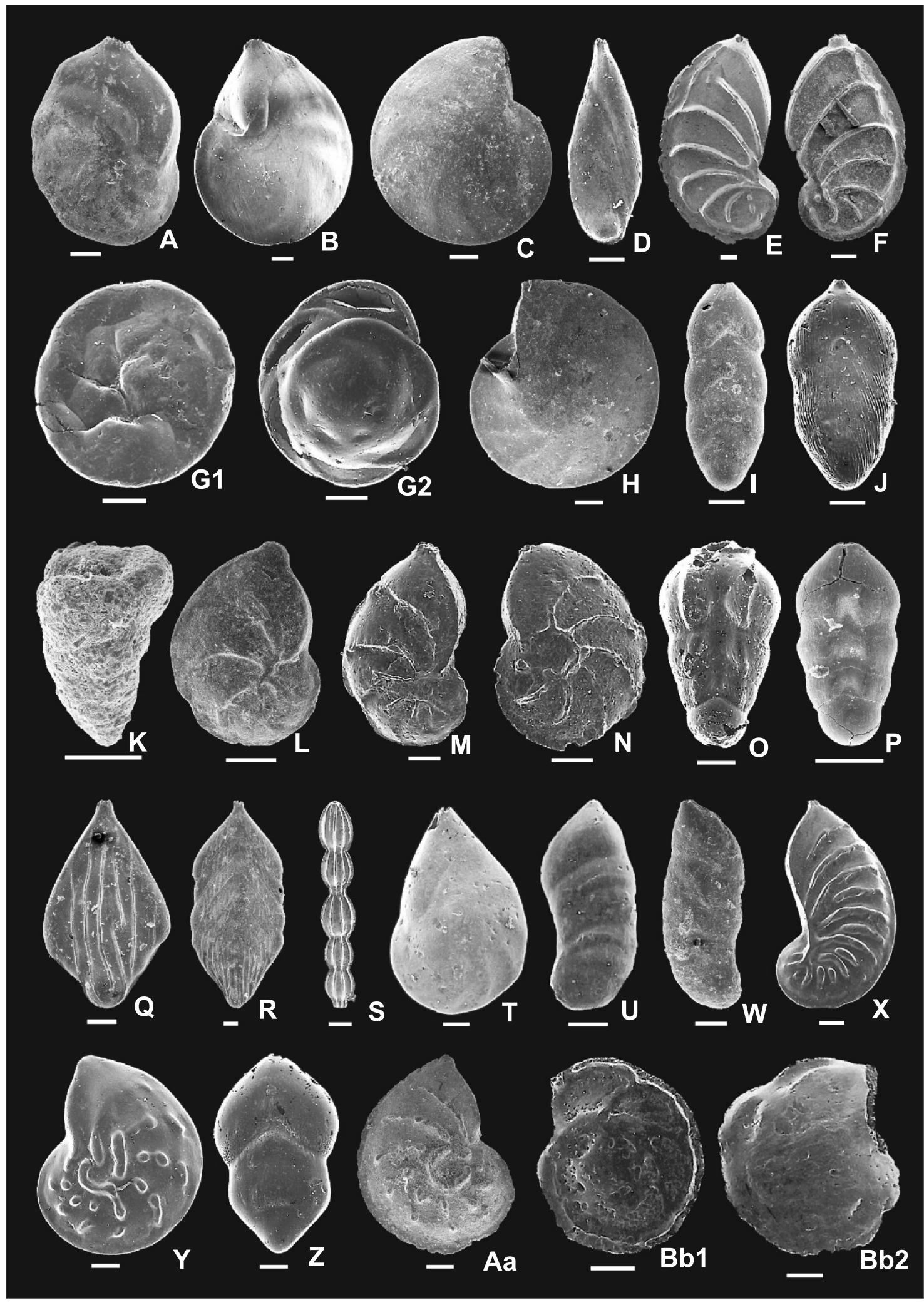

Fig. 8. Foraminifers from the Callovian deposits of the Polish Lowlands

A - Lenticulina okrojanzi (collection of Smoleń, 2000); B, C - Lenticulina tumida (collection of Smoleń, 2000); D - Planularia colligata (collection of Smoleń, 2000); E - Planularia tricarinella (collection of Smoleń, 2000); F - Planularia tricostata (collection of Smoleń, 2000); G1 Pseudolamarckina rjasanensis, ventral side (collection of Smoleń, 2000); G2 - Pseudolamarckina rjasanensis, dorsal side (collection of Smoleń, 2000); H - Lenticulina ruesti (collection of Smoleń, 2000); I, J - Ichtyolaria supracalloviensis (collection of Smoleń, 2000); K Dorothia osowiensis (collection of Bielecka and Styk, 1981); L, M - Lenticulina lithuanica (collection of Smoleń, 2000); N - Lenticulina polonica (collection of Smoleń, 2000); O, P - Geinitzinita crassata (collection of Smoleń, 2000); Q - Citharinella moelleri (collection of Bielecka and Styk, 1981); R - Citharinella nikitini (collection of Bielecka and Styk, 1981); S - Nodosaria mutabilis (collection of Smoleń, 2000); T - Lenticulina ovato acuminata (collection of Smoleń, 2000); U, W - Astacolus erucaeformis (collection of Smoleń, 2000); X Saracenaria engelsensis (collection of Smoleń, 2000); Y - Lenticulina papillaecostata (collection of Smoleń, 2000); Z - Pachyphloides glandulinoides (collection of Smoleń, 2000); Aa - Lenticulina quenstedti (collection of Smoleń, 2000); Bb1 - Epistomina planiconvexa, dorsal side (collection of Smoleń, 2000); Bb2 - Epistomina planiconvexa, ventral side (collection of Smoleń, 2000); scale bars - $100 \mu \mathrm{m}$ 
batrakiensis (Mjatliuk), Saracenaria engelsensis Kosyreva (Fig. 8X), Planularia paralella (Schwager) (Fig. 9F), Palmula subparalella (Wiśniowski), Epistomina planiconvexa Bielecka et Styk (Fig. 8Bb1, Bb2), Ophthalmidium carinatum marginatum (Wiśniowski) (Fig. 9D, E), Palaeomiliolina michalskii (Wiśniowski) (Fig. 9A, B), P. difficilis (Wiśniowski) (Fig. 9C), Lenticulina papillaecostata Bielecka et Styk (Fig. 8Y), L. laminaesuturata Bielecka et Styk and Pachyphloides glandulinoides (Wiśniowski) (Figs. 7 and 8Z).

The Callovian foraminiferal assemblages are characterized by a considerable proportion of taxa described form northeastern European regions. Taxonomic analysis of Upper Callovian foraminiferal assemblages from NE Poland has allowed distinguishing the foraminiferal Lenticulina tumida Zone (Grigelis, 1982) within the limits of the ammonite zones of Duncani (= Athleta) and Lamberti (Smoleń, 2000). Such zone was previously established by Grigelis $(1982,1985)$ and Mesezhnikov et al. (1989) within the range of the Athleta and Lamberti zones in the European part of the East European Platform.

In the remaining part of the Polish Lowlands, where the Upper Callovian is represented by the nodular bed or by organodetrital limestones (eastern Poland), which are often diagenetically changed, foraminifera microfossils are preserved rarely (Dayczak-Calikowska and Marcinkiewicz, 1997). In south-central Poland (Kraków-Wieluń Upland), relatively large Upper Callovian foraminiferal assemblages have been found locally only in marly and clayey deposits in the south of the Kraków-Wieluń Upland (Wiśniowski, 1890; Bielecka, 1960a; Olszewska and Wieczorek, 1988; Siewniak, 1962). In the north of the upland, between Częstochowa and Zawiercie, Kopik (1998) has determined only a few foraminiferal species in the lower Upper Callovian (Athleta Zone). At the end of the Middle Jurassic, most foraminiferal species have their last occurrences. The Oxfordian deposits contain only few Middle Jurassic species.

\section{UPPER JURASSIC}

\section{OXFORDIAN}

A clear differentiation in palaeogeographical provinces is observed in Europe during the Oxfordian. In the Polish Lowlands, an epicontinental marine basin existed at that time, which was connected to the Tethys Ocean and the northern seas (e.g., Marek and Pajchlowa, 1997; Fig. 10). Different sedimentary conditions in the individual parts of the Polish Basin and varying influences from the palaeogeographical provinces greatly affected the development of ammonite faunas. Faunal assemblages show significant differences between southern, eastern and central Poland (with typically different types of sponge megafacies carbonates) and the regions of northern Poland (with mudstone-claystone and mudstone-sandstone deposits of the Łyna Formation; Fig. 11). The presence of ammonites, characteristic of different palaeogeographical provinces, resulted in the usage of different stratigraphic schemes in Poland. They were based on either Boreal or Submediterranean divisions.

Over the last few decades, much work has been carried out on biostratigraphical correlations of the Oxfordian and Kimmeridgian between the individual provinces. The research has resulted in both the correlation of ammonite zonation between the Subboreal, Boreal and Submediterranean biogeographical provinces, and the proposal of unification of the Oxfordian/Kimmeridgian boundary for all palaeogeographical provinces. A substantial change refers to the position of this boundary in the Submediterranean Province. According to the recently proposed scheme, the boundary is placed between the Hypselum and Bimammatum zones. The lower boundary of the new substage corresponds to the lower boundary of the Subboreal ammonite zone of Baylei, and to the lower boundary of the Boreal zone of Bauhini (Wierzbowski and Matyja, 2014; Wierzbowski et al., 2015, 2016). As a result of the redefined Oxfordian division in the Submediterranean Province, the Hypselum Subzone (previously a subzone of the Bimammatum Zone) has been elevated to the rank of 'zone', and the Bimammatum and Planula zones have been moved to the Kimmeridgian (see Wierzbowski et al., 2016: p. 30, fig. 7). At the same time, the new proposal of the lower boundary of the unified Upper Oxfordian Substage in the Submediterranean Province has been put up by Głowniak (2006a) who considers this boundary as coeval with the base of the redefined Bifurcatus Zone (with the Wartae Subzone as the basal subzone of the Bifurcatus Zone). Simultaneously, the so-defined lower boundary of the Bifurcatus Zone corresponds to the boundary between the Middle and Upper Oxfordian substage (Głowniak 2006a). The aim of this change was to obtain a close correlation of the lower boundaries of the Upper Oxfordian Substage between the Boreal and the Submediterranean provinces. The lower boundary of the Boreal Upper Oxfordian lies close to, but somewhat below the equivalent substage boundary in the Submediterranean Province, falling in the uppermost part of the Transversarium Zone (cf. Matyja and Wierzbowski, 1994; Głowniak 2006a; Wierzbowski et al., 2015).

\section{FORAMINIFERAL ASSEMBLAGES: CENTRAL, SOUTHERN} AND EASTERN POLAND

In the southern, eastern and central parts of Poland, the Oxfordian basin was an area of carbonate sedimentation (sponge megafacies). The Early Oxfordian was dominated by sedimentation of the Spongy Limestone Formation. In the Middle Oxfordian, the Coraliferous Formation developed in some areas of central and eastern Poland. The Late Oxfordian was a period of the oolithic limestone (Oolithic Formation) development (see Niemczycka, 1997).

The first micropalaeontological reports on the characteristics of foraminiferal assemblages and their stratigraphical significance dealt with data from exposures and boreholes in the Kraków-Wieluń Upland (Bielecka, 1956, 1960a; Olszewska and Wieczorek, 1988, Siewniak, 1962), as well as from boreholes drilled in central (Bielecka, 1960b, 1961; Bielecka and Styk, 1964, 1968) and eastern Poland (Bielecka, 1964). The works and numerous archived micropalaeontological documentations of boreholes drilled in these parts of the Polish Lowlands resulted in the compilation of charts of the range of the most important foraminiferal species, correlated with the regional biostratigraphhic schemes and presented by Bielecka (1980) and Styk (1997). In the above-mentioned publications, the age ranges of the Oxfordian foraminiferal species were correlated with the ammonite biostratigraphy established by Malinowska (1976, 1991a, b), which was based on ammonites typical of the Boreal and Sub-Boreal provinces, and with reference to the stratigraphic divisions established for these provinces. The results of the latest research on the distribution of ammonite faunas in the sponge megafacies deposits show unambiguously the dominance of Submediterranean species and the validity of the Submediterranean stratigraphic scheme for these areas (Głowniak, 2002, 2006a, b, 2012; Wierzbowski and Matyja, 2014; Wierzbowski et al., 2015, 2016).

Correlation of the stratigraphic ranges of foraminiferal species in the sponge megafacies deposits with the standard 


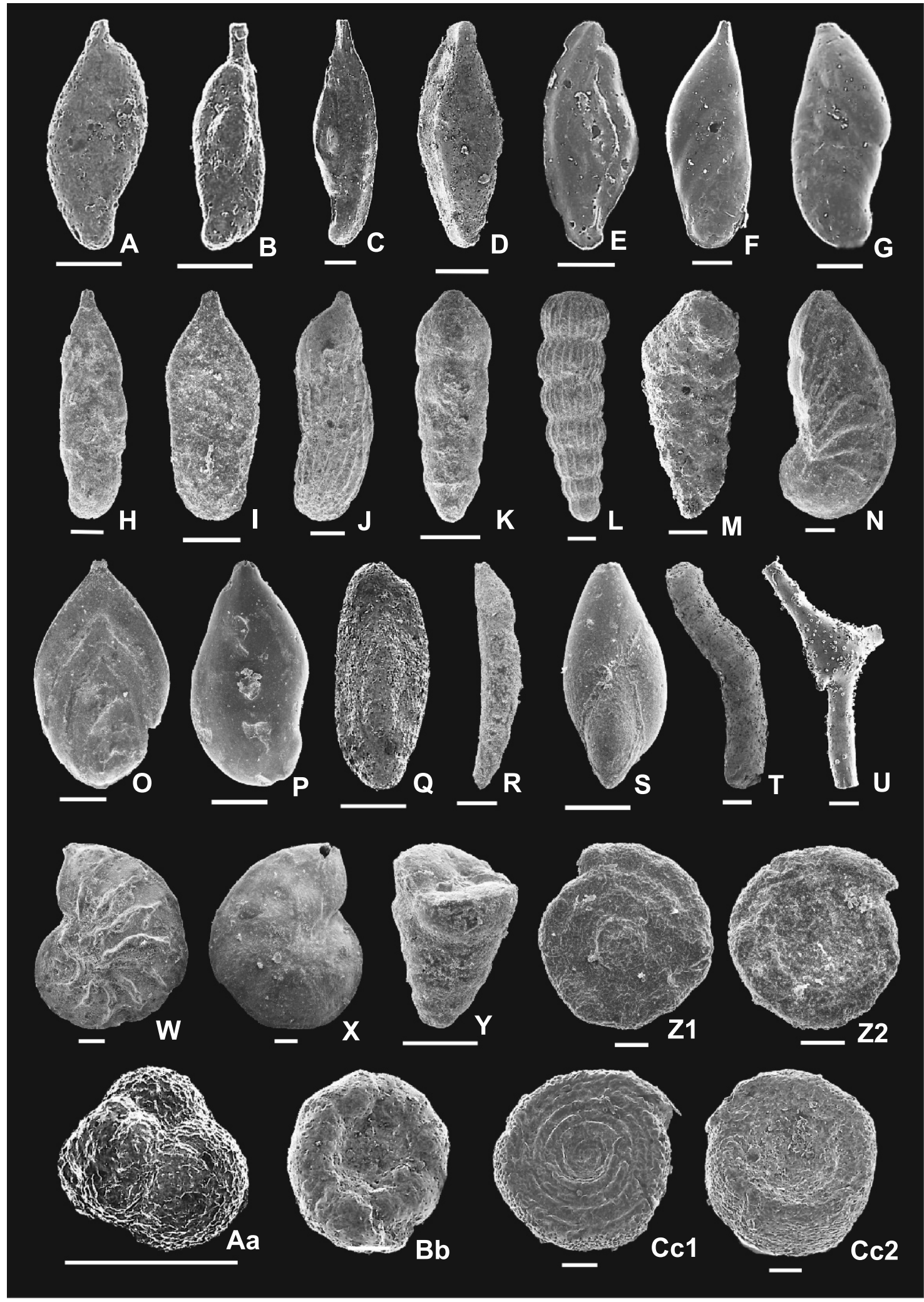

Fig. 9. Foraminifers from the Upper Callovian deposits (A-G) and Oxfordian Sponge Megafacies carbonates (H-Cc2) of the Polish Lowlands

A, B - Palaeomiliolina michalskii (collection of Smoleń, 2000); C - Palaeomiliolina difficilis (collection of Smoleń, 2000); D, E Ophthalmidium carinatum marginatum (collection of Smoleń, 2000); F - Planularia paralella (collection of Smoleń, 2000); G - Astacolus folium (collection of Smoleń, 2000); H, I - Palmula subparalella (collection of Bielecka, 1960); J - Marginulinopsis radiata (collection of Bielecka, 1960); K - Lingulina laevissima (collection of Bielecka, 1960); L - Nodosaria raphanistriformis (collection of Bielecka, 1960); M Textularia jurassica (collection of Smoleń, 1998); N - Saracenaria cornucopiae (collection of Smolen, 1998); O - Falsopalmula deslongchampsi ( (collection of Smoleń, 1998); P - Astacolus folium (collection of Bielecka, 1960); Q - Miliammina olgae (collection of Smoleń, 1998); R - Dentalina jurensis (collection of Bielecka, 1960); S - Eoguttulina oolithica (collection of Bielecka, 1960); T - Soccorhisa ramosa (collection of Smoleń, 1998); U - Ramulina spandeli (collection of Smoleń, 2015); W - Lenticulina quenstedti (collection of Smoleń, 2015); X - Lenticulina calva (collection of Bielecka, 1960); Y - Dorothia jurassica (collection of Bielecka, 1960); Z1 - Spirillina tenuissima (collection of Smoleń, 1998); Z2 - Spirillina tenuissima (collection of Smoleń, 1998); Aa - Globuligerina oxfordiana (collection of Smoleń, 1998); Bb - Spirillina polygyrata (collection of Smoleń, 1998); Cc1 - Spirillina andrea (collection of Smoleń, 1998); Cc2 - Spirillina andrea (collection of Smoleń, 1998); scale bars $-100 \mu \mathrm{m}$ 


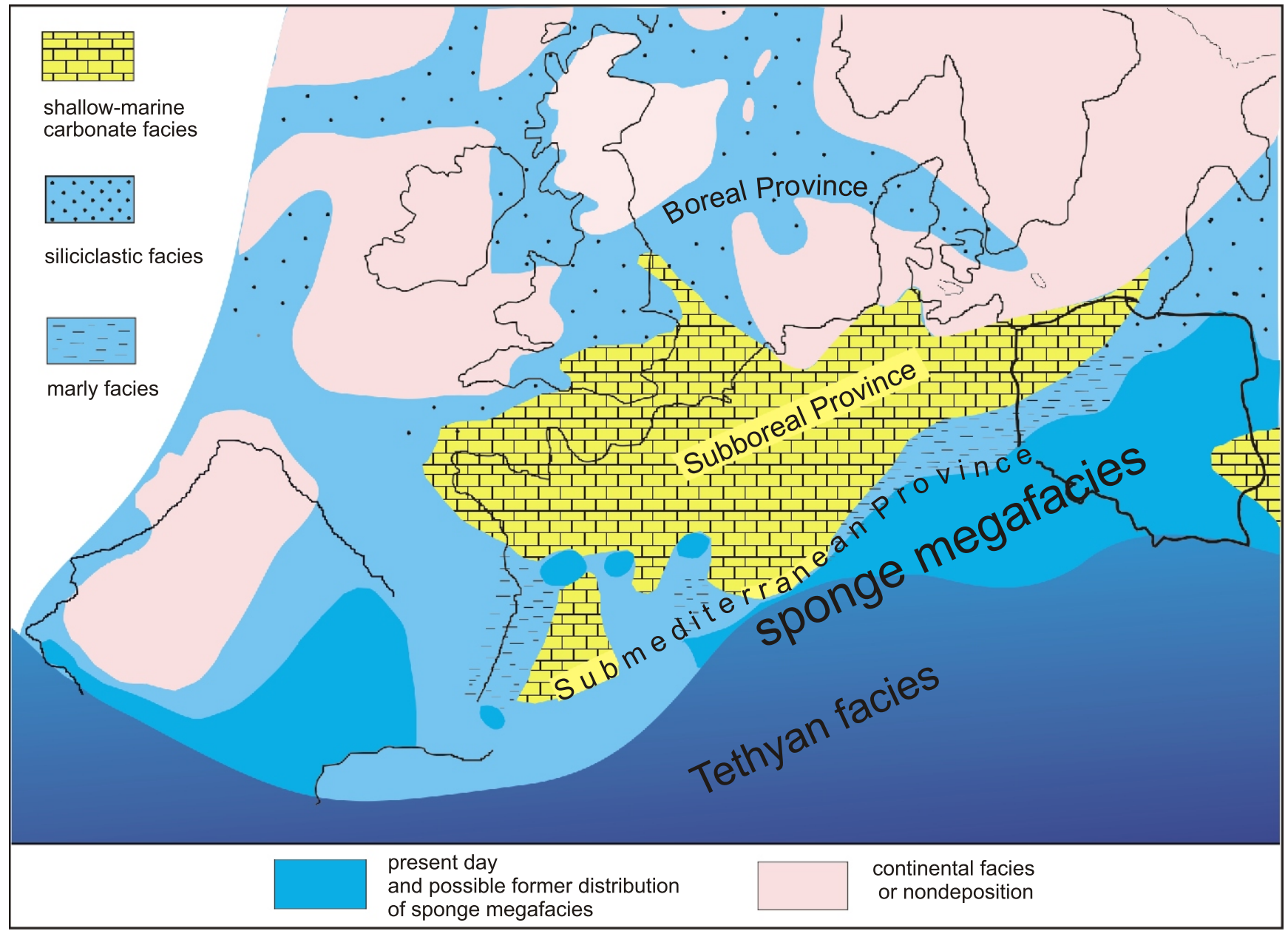

Fig. 10. Palaeogeographic reconstruction showing facies distribution in the Middle to Late Oxfordian transition in Europe (after Matyja and Wierzbowski, 1995)
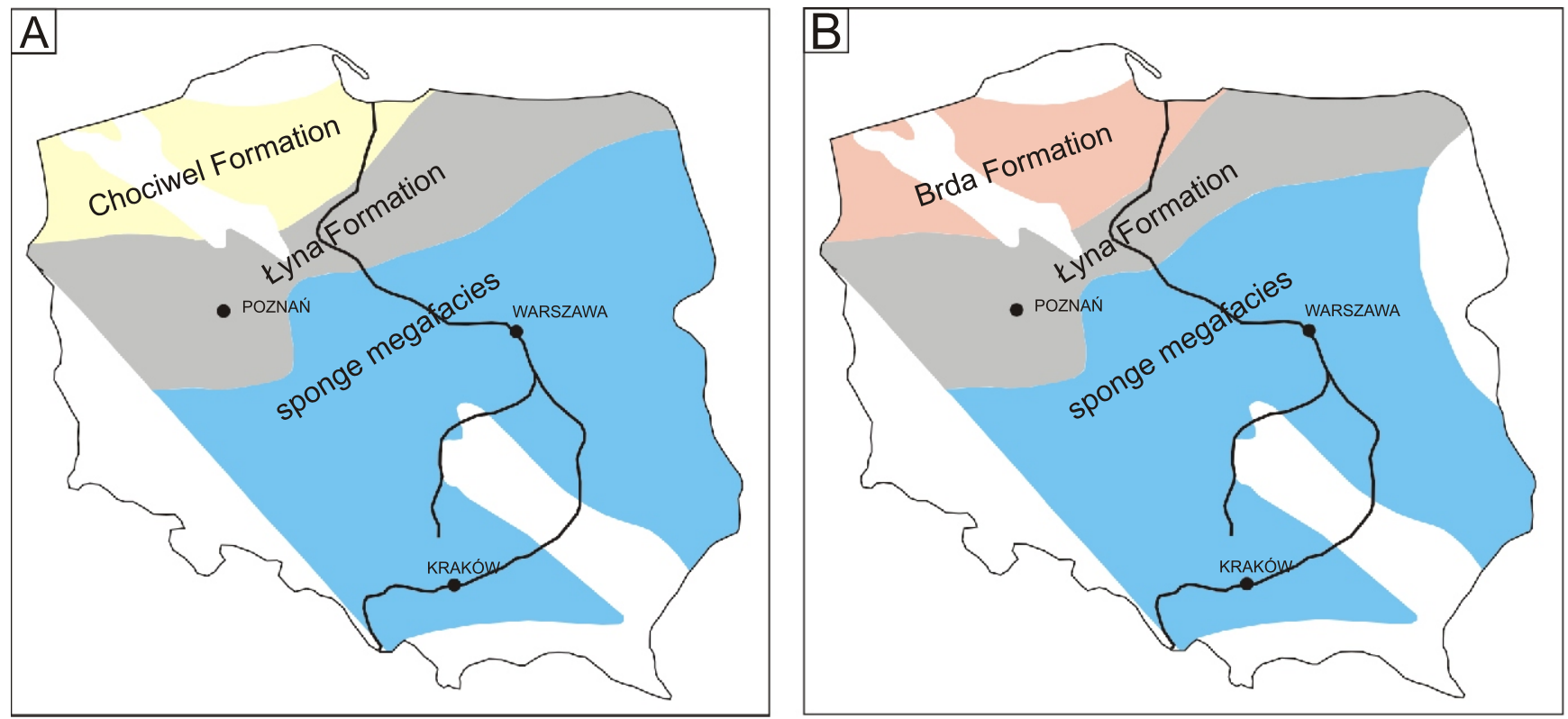

Fig. 11. Sketch of the distribution of lithostratigraphic units of the Lower Oxfordian (A) and Upper Oxfordian-Lower Kimmeridgian (B), after Niemczycka (1997, modified) 
ammonite divisions is currently hindered due to the lack of simultaneous research on ammonite and foraminiferal faunas in typical sponge megafacies sections. Such a correlation has so far been possible in the Kcynia IG-4 borehole (Fig. 12), where detailed revision of the ammonite fauna, previously studied by Dembowska (1964) and later by Malinowska (1966, 1981, 1991a), has been made (Matyja and Wierzbowski, 1998). As proved by the latter authors, ammonites diagnostic for the Submediterranean Province account for $>60 \%$ of all examined specimens in the Kcynia IG-4 borehole. This enables distinguishing of the Submediterranean ammonite zones. It must be stressed that the Kcynia IG-4 borehole (Fig. 1) is located in the northwestern part of central Poland within an area of silty-clayey-marly facies of the Łyna Formation adjoined to the south by carbonates of the sponge megafacies. Taxonomic analysis of foraminifers, which were described by Bielecka and Styk (1964) in the Kcynia IG-4 borehole, shows that all foraminifers from this borehole were also reported from the carbonate deposits of the sponge megafacies in many works (e.g. Bielecka, 1960a; Siewniak, 1962; Bielecka and Styk, 1968; Smoleń, 1998, 2012c, 2015; Olszewska, 2014). This fact allows a correlation of stratigraphic ranges of the foraminiferal species found in the Kcynia IG-4 borehole with the ammonite zones of the Submediterranean Province (Fig. 12).

With respect to the conclusions of the Kcynia IG-4 borehole studies and analysis of previous micropalaeontological reports (mentioned above), a chart of the stratigraphic ranges of the most important foraminiferal species, characteristic of carbonate deposits of the sponge megafacies in the Polish Lowlands has been compiled (Fig. 13). However, precise determination of the age ranges of the important foraminiferal species requires further correlations based on the latest data on the Oxfordian standard stratigraphic divisions.

Over much of the area of southern, central and eastern Poland, the Lower Oxfordian sedimentary series starts with condensed deposits of the so-called nodular bed yielding an ammonite fauna of the uppermost Callovian (Lamberti Zone) and the lowermost Oxfordian (Mariae Zone). These deposits contain both Callovian and Lower Oxfordian foraminiferal assemblages which unfortunately cannot be used for precise stratigraphic correlations.

In the southern part of the Kraków-Wieluń Upland, near Chrzanów (Bielecka, 1960a) and Olkusz (Siewniak, 1962), where clay-marly deposits locally occur, microfaunal assemblages contain not only Upper Callovian taxa but also typical Oxfordian foraminiferal species, including Spirillina tenuissima Gümbel (Fig. 9Z1, Z2), Textularia jurassica (Gümbel) (Fig. 9M), Lingulina laevissima (Terquem) (Fig. 9K), Marginulinopsis radiata (Terquem) (Fig. 9J), Nodosaria raphanistriformis (Gümbel) (Fig. 9L), Dentalina jurensis (Gümbel) (Fig. 9R), Saracenaria cornucopiae (Schwager) (Fig. 9N), Lenticulina calva (Wiśniowski) (Fig. 9X), L. rotulata (Lamarck) and Ramulina spandeli Paalzow. Above the nodular bed in southern, central and eastern Poland, the Oxfordian section is represented by various types of limestones and marls of the so-called sponge megacies characteristic of the northern shelf of the Tethys Ocean.

A number of new species appear in the upper Lower Oxfordian (upper part of the Cordatum Zone; Fig. 13), which reached their acme in the Middle Oxfordian - a time of "Mediterranean Spread" (Głowniak, 2006b). The Middle Oxfordian deposits of the Plicatilis and Transversarium zones reveal the presence of large foraminiferal assemblages in terms of the number of both species and individuals. The species diversity within the assemblages is manifested only by changes in the number of individuals of particular taxa within the assemblage, depending on the lithology. The largest assemblages are found in the facies of marly limestones and marls. A decrease in the number of foraminifers was noted in biohermal facies and various types of bedded limestones of interbiohermal zones in south-central Poland in the Kraków-Wieluń Upland (Bielecka, 1960a; Smoleń 1998; Olszewska, 2014) and in central Poland in the Wojszyce and Brześć Kujawski boreholes (Smoleń, 2008b, 2012c). The characteristic species, representing the time interval from the latest Early Oxfordian (upper part of the Cordatum Zone) to the latest Middle Oxfordian (Transversarium Zone), comprise the following taxa (Fig. 13): Spirillina polygyrata Gümbel (Fig. 9Bb), S. tenuissima Gümbel, S. andrea Bielecka (Fig. 9Cc1, Cc2), Ophthalmidium carinatum marginatum (Wiśniowski), Paalzowella feifeli seiboldi Lutze (Fig. 14L), P. turbinella (Gümbel) (Fig. 14M1, M2) and Globuligerina oxfordiana Grigelis (Fig. 9Aa), which occur locally as large accumulations. The above-listed species are commonly accompanied by Miliammina olgae Bielecka (Fig. 9Q), Planularia polypora (Gümbel) (Fig. 14A, B), P. beierana (Gümbel) (Fig. 14F), Citharina flabellata (Gümbel) (Fig. 14C, D), C. lepida (Schwager) (Fig. 14E), Falsopalmula deslongchampsi (Terquem) (Fig. 90), Saracenaria cornucopiae (Schwager), Soccorhisa ramosa (Brady) (Fig. 9T), Nubeculinella infraoolithica (Terquem) (Fig. 140), Ramulina spandeli Paalzow (Fig. 9U), Lenticulina ruesti (Wiśniowski), L. calva (Wiśniowski), L. quenstedti (Gümbel) (Fig. 9W) and L. rotulata (Lamarck), Astacolus folium (Wiśniowski) (Fig. 9P), Eoguttulina oolithica (Terquem) (Fig. 9S), Guttulina jurassica (Gümbel) (Fig. 14K) and Dorothia jurassica (Mitjanina) (Fig. 9Y). The remaining species present in deposits of the above-mentioned time interval occur in small quantities (see Fig. 13). At the end of the Middle Oxfordian, some species have their last occurrences, including Miliammina olgae Bielecka, Marginulinopsis radiata (Terquem), Textularia jurassica (Gümbel), Lenticulina ruesti (Wiśniowski) and Palmula subparalella (Wiśniowski) (Bielecka, 1960a). The Upper Oxfordian microfauna is very poor in both species and individuals. The foraminiferal assemblages are similar to those found in older deposits as regards their species composition, but less abundant with respect to the quantity of individuals. Most of the taxa have their upper limits of stratigraphic ranges. The typical species for the Upper Oxfordian deposits are: Paalzowella feifeli elevata Lutze (Fig. 14N), Patellinella cristinae Bielecka (Fig. 14I, J), Trocholina nodulosa Seibold et Seibold, Discorbis speciosus Dain (Fig. 14H) and D. subspeciosus Bogdanonvich et Makarjeva (Fig. 14G1, G2). Relatively abundant are Spirillina polygyrata Gümbel, S. tenuissima Gümbel, Paalzowella feifeli seiboldi Lutze and $P$. turbinella (Gümbel), and some lenticulinids. These assemblages are representative of the Spongy Limestone Formation of south-central and central Poland (e.g., Bielecka, 1960a; Smoleń, 2008b, 2012c).

In SE Poland, where the shallow-marine coral facies developed during the Bifurcatus Zone, the foraminiferal assemblages are highly depleted. In the uppermost Oxfordian Hypselum Zone, a further decrease in the number of both species and individuals is observed in the foraminiferal assemblages (Bielecka, 1960a). They contain single specimens of taxa known from the older Oxfordian deposits, which were tolerant to varying marine environmental conditions: Spirillina tenuissima Gümbel, S. polygyrata Gümbel, Paalzowella turbinella (Gümbel), P. feifeli elevata Lutze, P. feifeli seiboldi Lutze, Patellinella cristinae Bielecka, Discorbis speciosus Dain, D. subspeciosus Bogdanonvich et Makarjeva, Lingulina laevissima (Terquem), A. folium (Wiśniowski), Dentalina jurensis (Gümbel), Eoguttulina oolilithica (Terquem), Planularia beierana (Gümbel) and others. The considerable depletion in foraminiferal abundance was related to the facies development. Particularly poor assemblages are found in compact limestones with a high content of calcium carbonate and in reefal-spongy limestones of Coraliferous Formation of central Poland (e.g., in the Wojszyce and Brześc Kujawski bore- 


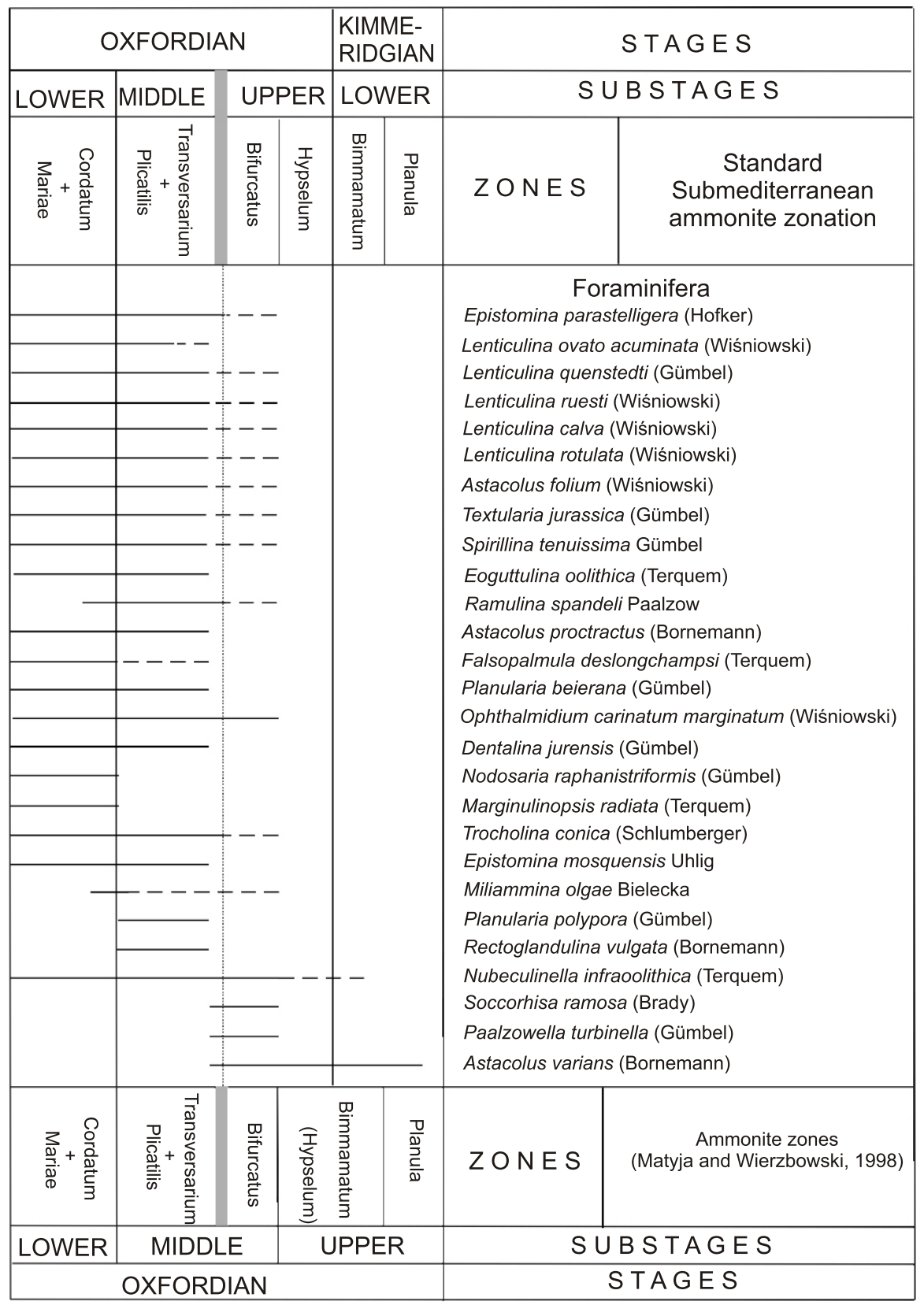

Fig. 12. Distribution of foraminifera species in the Kcynia IG-4 borehole and the correlation of the standard Submediterranean Oxfordian ammonite zonations as proposed by Głowniak (2002, 2006a), Wierzbowski and Matyja (2014) and Wierzbowski et al. (2015) with the previous Oxfordian subdivision as used by Matyja and Wierzbowski (1998)

Grey blocks indicate the intervals of stratigraphic confidence

holes - Smoleń, 2008b, 2012c). In the eastern regions of the Polish Lowlands, where the oolithic and organodetritic limestones of the Oolithic Formation predominate, foraminiferal microfauna is observed sporadically.

FORAMINIFERAL ASSEMBLAGES: NORTHERN AND NORTHEASTERN POLAND

In the northern and northeastern part of the Polish Lowlands, Oxfordian deposits are represented by terrigenous formations. In most areas of $\mathrm{N}$ and NE Poland, they are composed of silty-clayey-marly facies (Łyna Formation). In the northwest- ern part, this formation comprises only the Lower Oxfordian, and is followed in the upper Oxfordian by the sandy-chlorite Chociwel Formation that was replaced at the end of the Oxfordian by the oolitic Brda Formation (Fig. 11).

During Oxfordian times, the territory of northern Poland was an area where the influences of various palaeogeographical provinces mixed: Submediterranean, Subboreal and Boreal, allowing periodic migration of ammonite faunas. Due to the nature of the deposits and variable influences of the individual palaeogeographical provinces, the facies generally contain foraminiferal assemblages different from those present in the spongy limestone facies of central, southern and eastern Po- 


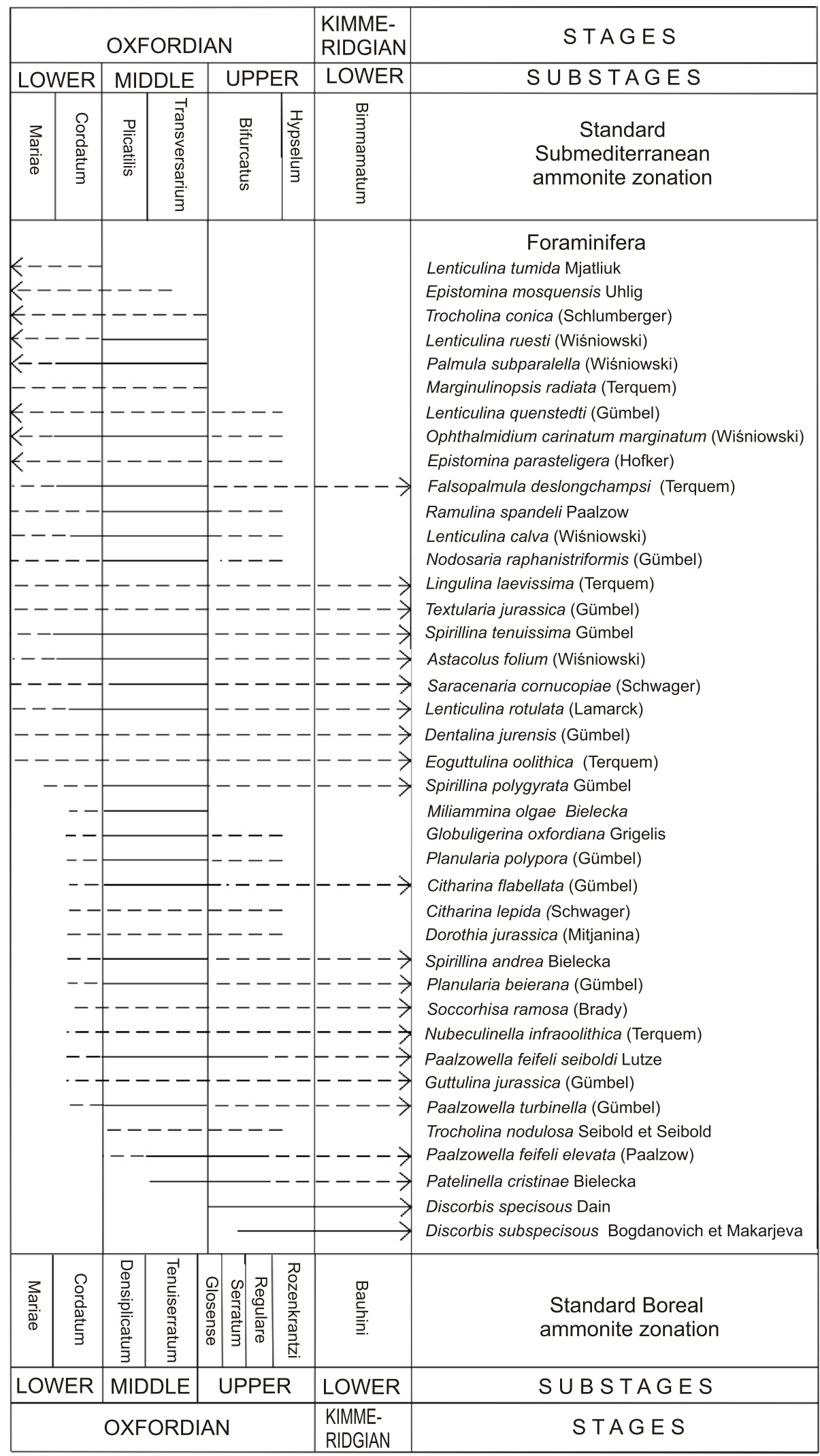

Fig. 13. Stratigraphic range charts of foraminifera species from the Oxfordian deposits of the Polish Lowlands (central, southern and eastern Poland); the Submediterranean standard ammonite zonation as used by Glowniak $(2002,2006 \mathrm{a})$ and correlation with the Boreal ammonite zonation as proposed by Wierzbowski et al. $(2014,2015)$ 


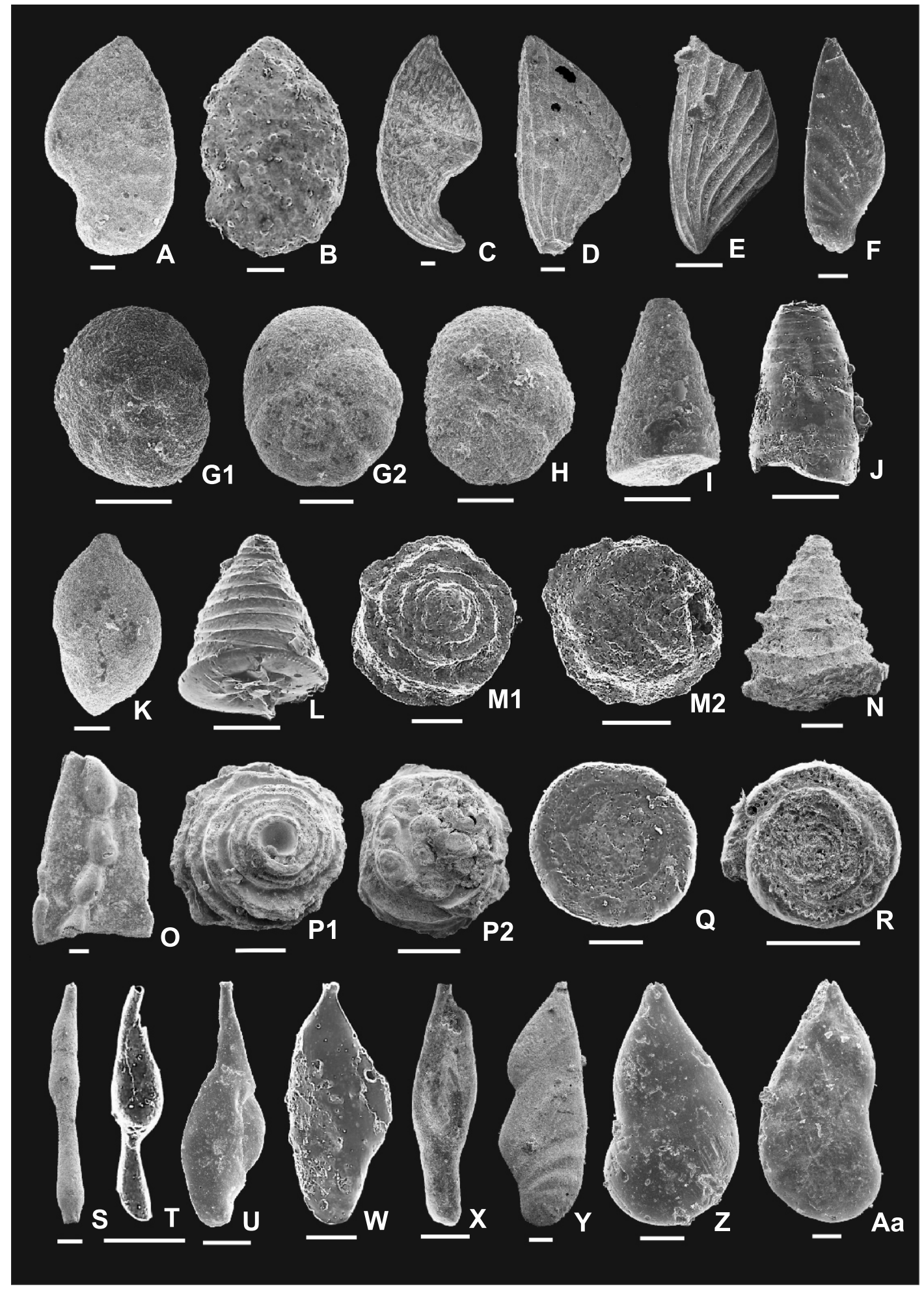

Fig. 14. Foraminifers from the Oxfordian carbonates (sponge megafacies) of the Polish Lowlands (A-O), Oxfordian silty-clayey-marly deposits of the Kyna Formation (Ophthalmidium sagittum-Epistomina volgensis Zone) of NE Poland (P1-Aa), and Oxfordian-Lower Kimmeridgian silty-clayey-marly deposits of the Łyna Formation (Lenticulina russiensis-Epistomina uhligi Zone) of NE Poland (X)

A - Planularia polypora (collection of Bielecka, 1960); B - Planularia polypora (collection of Smoleń 1998); C - Citharina flabellata (collection of Bielecka, 1960); D - Citharina flabellata (collection of Bielecka, 1960); E - Citharina lepida (collection of Bielecka, 1960); F - Planularia beierana (collection of Smolen 1998); G1 - Discorbis subspecisous (collection of Bielecka 1980); G2 - Discorbis subspecious (collection of Bielecka 1980); H - Discorbis specisous (collection of Bielecka 1980); I - Patelinella cristinae (collection of Bielecka 1960); $\mathbf{J}$ - Patelinella cristinae (collection of Smoleń 1998); K - Guttulina jurassica (collection of Bielecka, 1960); L - Paalzowella feifeli seiboldi (collection of Smoleń, 1998); M1 - Paalzowella turbinella (collection of Smoleń, 1998); M2 - Paalzowella turbinella (collection of Smoleń, 1998); N Paalzowella feifeli elevata (collection of Bielecka, 1960); O - Nubeculinella infraoolithica (collection of Smoleń, 1998); P1 - Trocholina transversarii (collection of Smoleń, 2015); P2 - Trocholina transversarii (collection of Smoleń, 2015); Q - Spirillina polygyrata (collection of Smoleń, 2015); R - Spirillina tenuissima (collection of Smoleń, 2015); S, T - Nubeculinella infraoolithica (collection of Smoleń, 2015); U Ophthalmidium sagittum (collection of Smoleń, 2000); W - Ophthalmidium strumosum (collection of Smoleń, 2015); Y - Planularia beierana (collection of Smoleń, 2015); Z - Lenticulina compressaeformis (collection of Smoleń, 2015); Aa - Lenticulina compressaeformis (collection of Smoleń, 2015); X - Ophthalmidium stuifense (collection of Smoleń, 2015); scale bars - $100 \mu \mathrm{m}$ 
land. The first micropalaeontological data concerning the characteristics of foraminiferal assemblages in the Oxfordian deposits of northern Poland and their stratigraphical significance are included in several publications (Bielecka and Dąbrowska 1958; Bielecka, 1960b, 1973, 1974; Bielecka and Styk, 1966, 1968) and in numerous archival micropalaeontological studies of particular boreholes drilled in this part of the Polish Lowlands. The analysis of previous studies shows that the largest foraminiferal assemblages are present in the silty-clayey-marly deposits of the Łyna Formation, except for the Kcynia IG-4 borehole, where the formaniferal assemblages are the same as in spongy limestones - see previous chapter.

In the areas extending north of the spongy megafacies, mixed foraminiferal assemblages are found with the vast majority of species being characteristic of the Subboreal Province. Such assemblages have been best documented in NE Poland where there is a complete Oxfordian section represented by silty-clayey-sandy facies. Oxfordian deposits of this region contain numerous foraminifers that were first described by Bielecka and Styk (1966) and Bielecka (1973, 1974). In those studies the age ranges of the described foraminiferal species were correlated with the ammonite biostratigraphy according to Malinowska (1966), which, in many cases, differs from the standard divisions used currently.

In recent times, detailed studies of the Oxfordian ammonite fauna and foraminiferal microfauna have been carried out in several well-cored boreholes (Pasłęk IG-1; Bartoszyce IG-1; Gołdap IG-1; Jastarnia IG-1; Krynica Morska IG-1; Fig.1) in the area of Peribaltic Syneclise (Smoleń, 2000, 2008c; Smoleń and Wierzbowski, 2012). A summary of these studies is published in a paper by Wierzbowski et al. (2015), which also provides a revision of earlier studies by Bielecka and Styk (1966) on the foraminiferal microfauna, as well as a revision of the ammonite stratigraphy proposed by Malinowska $(1966,1987,1991 a)$. The numerous and palaeogeographically diverse ammonite fauna from the Peribaltic Syneclise has allowed a correlation of the ammonite zonation between the Subboreal, Boreal and Submediterranean provinces, and standardization of the Oxfordian/Kimmeridgian boundary across these provinces (Fig. 15). In the context of the new stratigraphic data and detailed chronostratigraphic interpretation of the ammonite fauna, this study provides a chart illustrating the age ranges of stratigraphically important Oxfordian foraminifera species representative of the Łyna Formation in NE Poland (Fig. 15). It also includes micropalaeontological data from other boreholes: Kętrzyn IG-1 (Smoleń, 2014c), Grudziądz IG-1 (Smoleń, 2011d), Darżlubie IG-1 (Smoleń, 2011c) and Malbork IG-1 (Smoleń, 2012d). In terms of taxonomy, the Oxfordian foraminiferal assemblages in the Łyna Formation of NE Poland are most similar to the assemblages described on the East European Platform in Lithuania and in the European part of Russia (e.g., Grigelis, 1985; Ustinova, 2012). These are ophthalminids-epistominids- and epistominids-lenticulinids-type assemblages classified as characterizing the Sub-Boreal Province (Basov, 1974; Azbel et al., 1991). The vertical succession of foraminiferal species found in Oxfordian deposits of the Peribaltic Syneclise in Poland has been the basis for distinguishing foraminiferal zones (Wierzbowski et al., 2015; Fig. 15). Such zones were already established earlier in areas of the East European Platform, in Lithuania and the European part of Russia (e.g., Grigelis,1982, 1985; Mesezhnikov et al., 1989; Ustinova, 2012).

The Ophthalmidium sagittum-Epistomina volgensis Zone (Grigielis, 1982) can be correlated with the Lower Oxfordian (Mariae, Cordatum zones) and the lowermost Middle Oxfordian (mostly with the lower part of the ammonite Densiplicatum Zone; Fig. 15). This foraminiferal zone is domi- nated by taxa which are widespread in the eastern part of the Peribaltic Syneclise, Lithuania and Russia, indicating strong influences of the Sub-Boreal Province.

The taxa include the index species for this zone: Epistomina volgensis Mjatliuk (Fig. 16A1, A2) and Ophthalmidium sagittum (Bykowa) (Fig. 14U) whose range is limited to the Lower Oxfordian and lower Middle Oxfordian. The other species characteristic of the Ophthalmidium sagittum-Epistomina volgensis Zone are Epistomina intermedia Mjatliuk (Fig. 16C), E. nemunensis Grigelis, E. stelligeraeformis Mjatliuk, E. gracilis Dain (Fig. 16B1, B2), E. multialveolata (Grigelis) (Fig. 16D1, D2), E. uhligi Mjatliuk (Fig.16E1, E2), E. parastelligera Hofker, Lenticulina brueckmanni (Mjatliuk) (Fig. 16G) and Planularia beierana (Gümbel) (Fig. 14Y). The Lower Oxfordian and lowermost Middle Oxfordian contain also some species known from the older deposits, among others Ichtyolaria supracalloviensis (Wiśniowski) and Lenticulina tumida Mjatliuk. The upper part of the Ophthalmidium sagittum-Epistomina volgensis Zone reveals the first occurrences of the following taxa: Lenticulina compressaeformis (Paalzow) (Fig. 14Z, Aa), Ophthalmidium strumosum (Gümbel) (Fig.14W), Globuligerina oxfordiana Grigelis, Nubeculinella infraoolithica (Terquem) (Fig. 14S, T), Spirillina tenuissima Gümbel (Fig. 14R), Spirillina polygyrata Gümbel (Fig. 14Q) and Trocholina transversari (Paalzow) (Fig. 14P1,P2). The above-listed taxa contain widely spread species, also known from the Submediterranean areas.

The Ophthalmidium strumosum-Lenticulina brestica Zone (Grigelis, 1982) can be correlated with a large part of the Middle Oxfordian (from the upper part of the Densiplicatum Zone to the Tenuiserratum Zone, and the Plicatilis and Transversarium zones) and the lower part of the Upper Oxfordian (the Glosense and Serratum zones, a part of the Regulare Zone, as well as a large part of the Bifurcatus Zone; Fig. 15).

Deposits of the Ophthalmidium strumosum-Lenticulina brestica Zone contain especially numerous specimens of species Ophthalmidium strumosum (Gümbel). In terms of species diversity, the dominant family is the Epistominidae, of which the species Epistomina volgensis Mjatliuk and E. stelligeraeformis Mjatliuk also occur in the lower part of the zone (upper part of the Densiplicatum Zone). Epistomina nemunensis Grigelis, E. intermedia Mjatliuk, E. gracilis Dain, E. multialveolata (Grigelis), E. parastelligera and E. perfidiosa Grigelis (Fig. 16F) are numerous throughout the entire zone. They are accompanied by the species E. uhligi Mjatliuk, Lenticulina brestica (Mjatliuk) (Fig. 16K), L. hebetata (Schwager), L. brueckmanni (Mjatliuk), L. simplex (Kübler et Zwingli) (Fig. 16I), L. russiensis (Mjatliuk) (Fig. 16L), L. belorussica (Mitjanina) (Fig. 16H), L. tympana Grigelis (Fig. 16J),Trocholina transversarii (Paalzow), Pseudolamarckina suvalkensis Grigelis (Fig. 160), Paulina furssenkoi Grigelis (Fig. 16M1, M2), P. makarensis Azbel (Fig. 16N1, N2) and others species.

Ophthalmidium strumosum-Lenticulina brestica Zone is dominated by microfauna characteristic of the cool Subboreal Province (Grigelis, 1982, 1985; Mesezhnikov et al., 1989). The deposits, which show predominance of ammonites from the Submediterranean Province, manifest an increased proportion of cosmopolitan foraminifera taxa that are also known from the Submediterranean areas, such as Globuligerina oxfordiana (Pazdro) (Fig. 16P), Nubeculinella infraoolithica (Terqem), Orthella bulbifera (Paalzow) (Fig. 16Q), O. paalzowi Bykowa (Fig. 16R), Paalzowella feifeli seiboldi Lutze (Fig. 16S), Ramulina spandeli Paalzow (Fig. 17B), Labalina milioliniformis (Paalzow) (Fig. 17D), Spirillina tenuissima Gümbel, S. polygyrata Gümbel, Planularia tricarinella (Reuss) (Fig. 17E), Textularia jurassica (Gümbel) (Fig. 17A), Miliammina cf. olgae Bielecka, and others. 


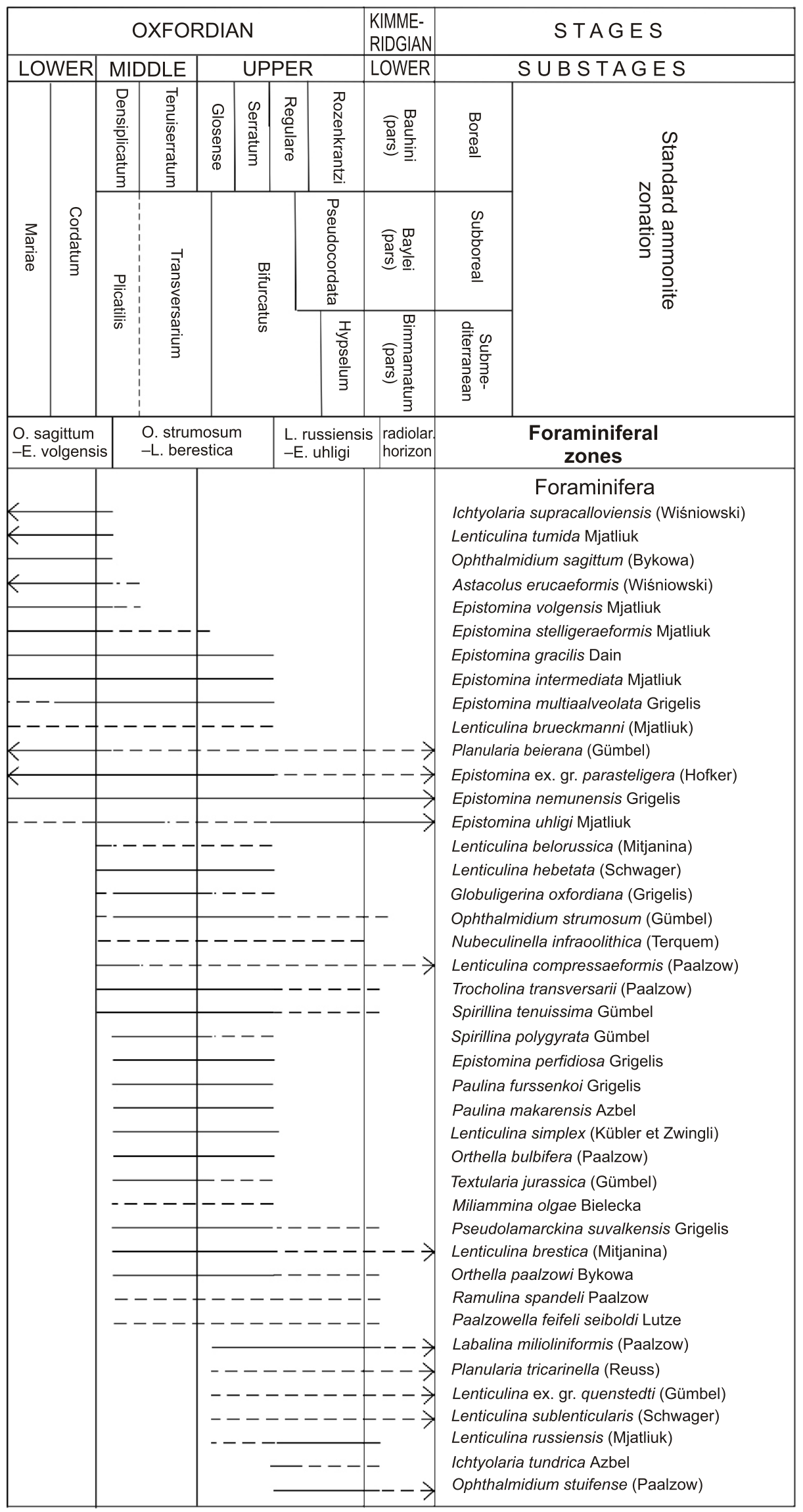

Fig. 15. Stratigraphic range charts of foraminifera species from the Oxfordian deposits of the Polish Lowlands ( $N$ and NE Poland); the correlation of the Boreal and Subboreal ammonite zonations (as proposed by Wierzbowski et al., 2014, 2015) with the Submediterranean zonation (as used by Głowniak, 2002, 2006a) 


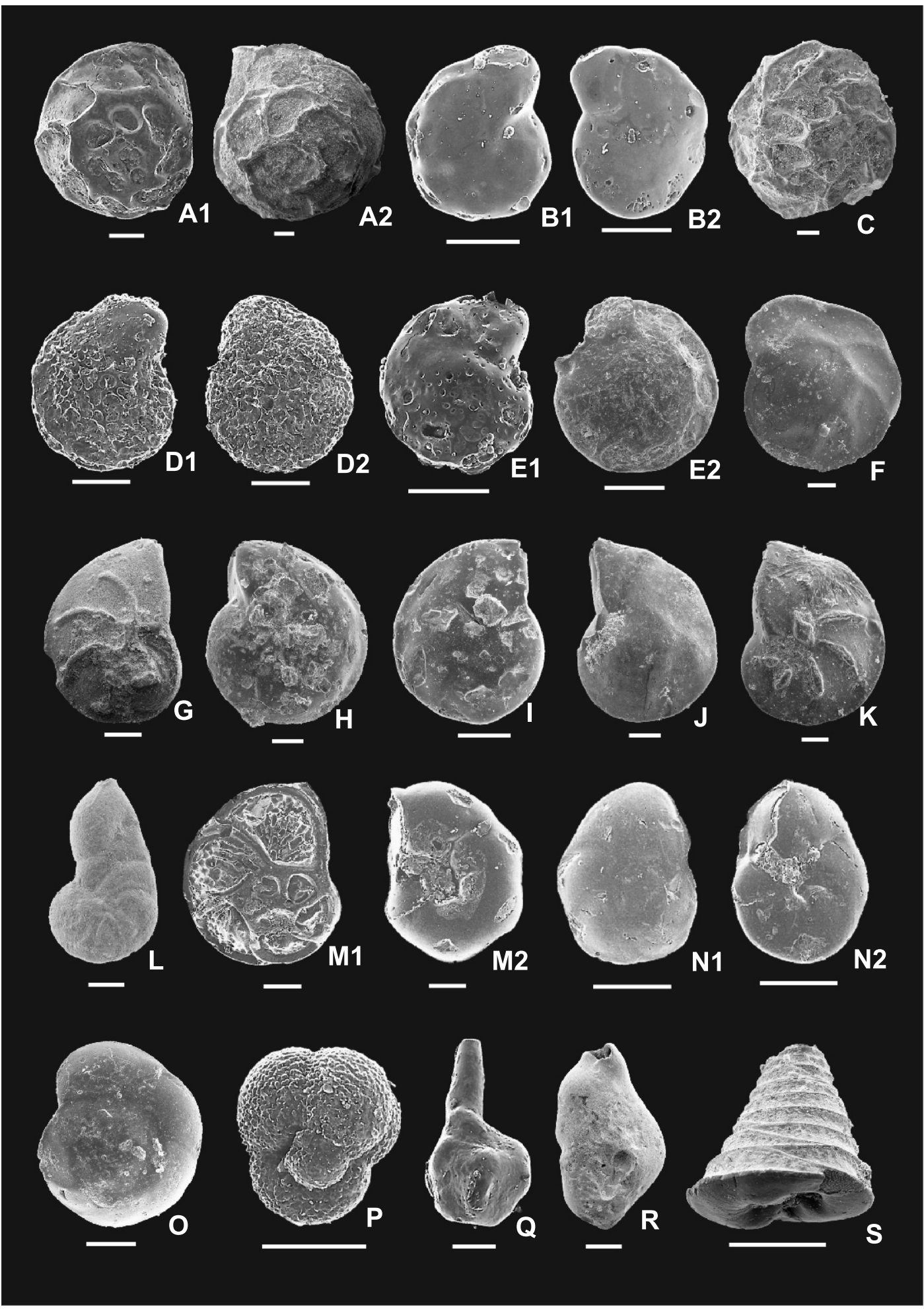

Fig. 16. Foraminifers of the Oxfordian silty-clayey-marly deposits of the Łyna Formation of NE Poland (Ophthalmidium sagittum-Epistomina volgensis Zone; A1-E2, G, and Ophthalmidium strumosum-Lenticulina brestica Zone, F, H-S) of NE Poland

A1 - Epistomina volgensis (collection of Smoleń, 2015); A2 - Epistomina volgensis (collection of Smoleń, 2015); B1 - Epistomina gracilis (collection of Smoleń, 2015); B2 - Epistomina gracilis (collection of Smoleń, 2015); C - Epistomina intermediata (collection of Smoleń, 2015); D1 - Epistomina multialveolata (collection of Smoleń, 2000); D2 - Epistomina multialveolata (collection of Smoleń, 2000 ); E1 Epistomina uhligi (collection of Smoleń, 2015); E2 - Epistomina uhligi (collection of Smoleń, 2015); F - Epistomina perfidiosa (collection of Smoleń, 2015); G - Lenticulina brueckmanni (collection of Smoleń, 2015); H - Lenticulina belorussica (collection of Smoleń, 2015); I Lenticulina simplex (collection of Smoleń, 2015); J - Lenticulina tympana (collection of Smoleń, 2015); K - Lenticulina brestica (collection of Smoleń, 2015); L - Lenticulina russiensis (collection of Smoleń, 2015); M1 - Paulina furssenkoi, dorsal side (collection of Smoleń, 2000); M2 - Paulina furssenkoi, ventral side (collection of Smoleń, 2000); N1 - Paulina makarensis, dorsal side (collection of Smoleń, 2000 ); N2 Paulina makarensis, ventral side (collection of Smoleń, 2000); O - Pseudolamarckina suvalkensis (collection of Smoleń, 2015); P _ Globuligerina oxfordiana (collection of Smoleń 1998); Q - Orthella bulbifera (collection of Smoleń, 2015); R - Orthella paalzowi (collection of Smoleń, 2015); S - Paalzowella feifeli seiboldi (collection of Smoleń, 2015); scale bars - $100 \mu \mathrm{m}$ 


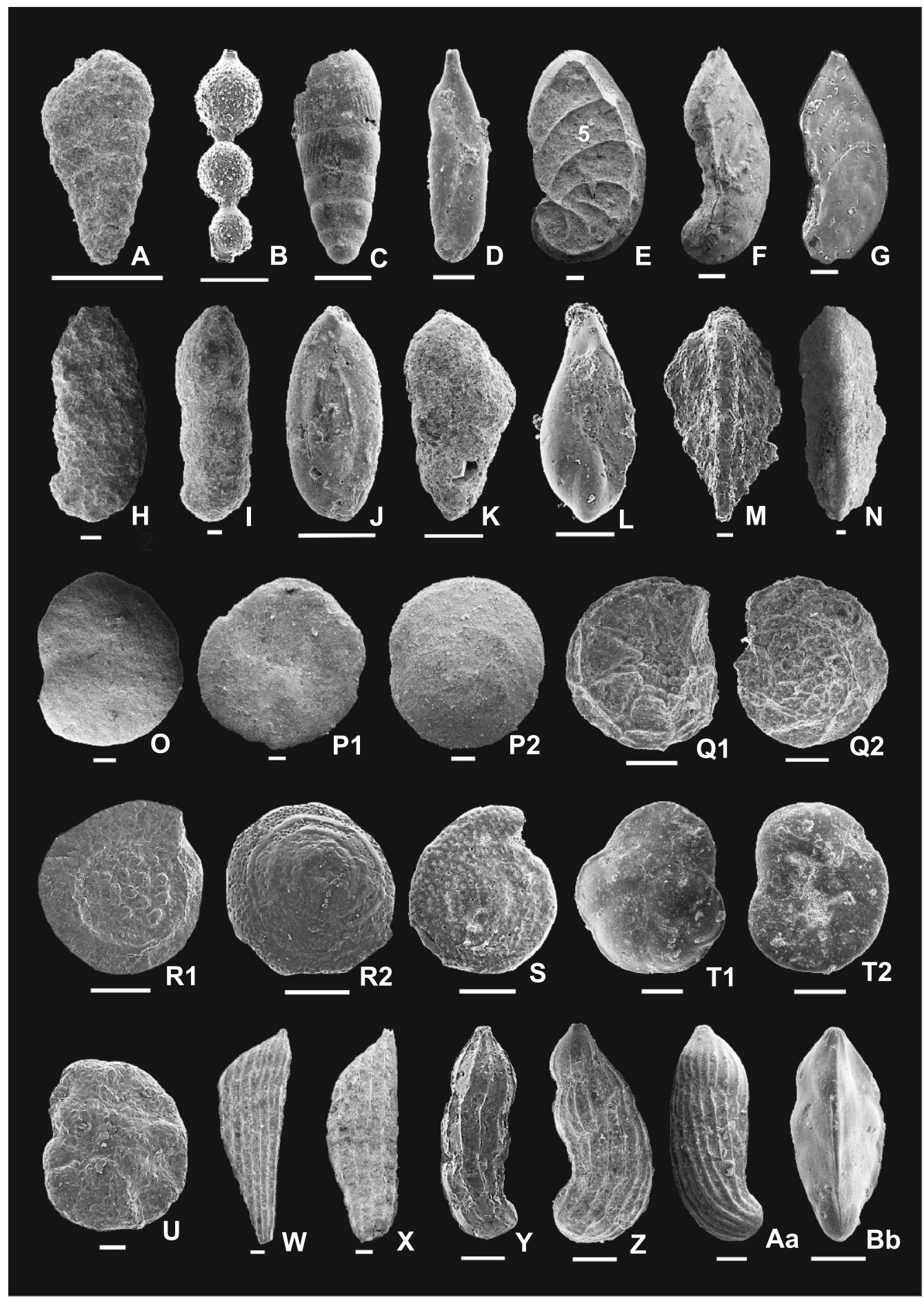

Fig. 17. Foraminifers of the Oxfordian silty-clayey-marly deposits of the Łyna Formation (Ophthalmidium strumosum-Lenticulina brestica Zone) of NE Poland (A, B), Oxfordian-Lower Kimmeridgian silty-clayey-marly deposits of the Łyna Formation (Lenticulina russiensis-Epistomina uhligi Zone) of NE Poland (C-E), Lower Kimmeridgian carbonate deposits of the Polish Lowlands (F-J, L-P2, U-Z) and Lower Kimmeridgian marly deposits of the Kyna Formation (Epistomina praetatariensis-Lenticulina kuznetsovae Zone) of NE Poland (K, Q1-T2, Aa, Bb)

A - Textularia jurassica (collection of Smoleń, 2015); B - Ramulina spandeli (collection of Smoleń, 2015); C - Ichtyolaria tundrica (collection of Smoleń, 2015); D - Labalina milioliniformis (collection of Smoleń, 2015); E - Planularia tricarinella (collection of Smoleń, 2015); F, G Saracenaria cornucopiae (collection of Bielecka, 1954); H - Ammobaculites infrajurensis (collection of Bielecka and Styk, 1980); I Ammobaculites coprolithiformis (collection of Bielecka and Styk, 1980); J - Quinqueloculina jurassica (collection of Bielecka, 1954); K Paleogaudryina varsoviensis (collection of Smoleń, 2015); L - Eoguttulina inovroclaviensis (collection of Smoleń, 2015); M, N - Triplasia althoffi jurassica (collection of Bielecka and Styk, 1980); O - Alveosepta jaccardi (collection of Bielecka and Styk, 1980); P1 Pseudolamarckina obliquicamerata, ventral side (collection of Bielecka and Styk, 1980); P2 - Pseudolamarckina obliquicamerata, dorsal side (collection of Bielecka and Styk, 1980); Q1 - Epistomina stellicostata, ventral side (collection of Smoleń, 2015); Q2 - Epistomina stellicostata, dorsal side (collection of Smoleń, 2015); R1 - Trocholina solecensis, ventral side (collection of Smoleń, 2015); R2 - Trocholina solecensis, dorsal side (collection of Smoleń, 2015); S - Spirillina infima (collection of Smoleń, 2015); T1 - Conorboides marginata, dorsal side (collection of Smoleń, 2015); T2 - Conorboides marginata, ventral side (collection of Smoleń, 2015); U - Haplophragmoides canui (collection of Bielecka and Styk, 1980); W, X - Citharina zaglobensis (collection of Smoleń, 2015); Y, Z - Marginulinopsis buskensis (collection of Smoleń, 2015); Aa - Marginulinopsis striatocostata (collection of Smoleń, 2015); Bb - Tristix suprajurassica (collection of Smoleń, 2015); scale bars $-100 \mu \mathrm{m}$ 
In the northernmost area of the Peribaltic Syneclise, the Łyna Formation deposits, present in the central syneclise, are replaced in the Middle and lowermost Upper Oxfordian by sandstones and sandy siltstones with iron oolites of the Chociwel Formation (documented by ammonites and foraminifers in the Jastarnia IG-1 borehole, Wierzbowski at al., 2015). These deposits yield large foraminiferal assemblages of the Ophthalmidium strumosum-Lenticulina brestica Zone. Throughout the whole territory of northeastern Poland, at the end of the Ophthalmidium strumosum-Lenticulina brestica Zone, the microfaunal assemblages become markedly poorer in terms of the number of taxa, and many of them are absent from the Upper Oxfordian rocks.

The Lenticulina russiensis-Epistomina uhligi Zone (Grigelis, 1982) corresponds to the uppermost Oxfordian (Rosenkrantzi Zone and possibly a part of the Regulare Zone, as well as the Pseudocordata Zone and the Hypselum Zone and possibly the uppermost part of the Bifurcatus Zone), but it covers also the basal part of the Lower Kimmeridgian (lowermost part of the Bauhini Zone, the Baylei Zone and the Bimmamatum Zone; Fig. 15). The foraminiferal assemblages of this zone are impoverished in terms of both the number of species and the quantity of specimens. They are represented by taxa occurring in the lower foraminiferal zones. The characteristic that allows distinguishing the zone is an increased proportion of the species Epistomina uhligi Mjatliuk, E. nemunensis Grigelis and Lenticulina russienis (Mjatliuk) in its deposits. Relatively numerous are also the species Labalina milioliniformis (Paalzow) and Lenticulina sublenticularis (Schwager). The remaining taxa distinguished in the Lenticulina russiensis-Epistomina uhligi Zone are present in a small number of individuals, including the species Ichtyolaria tundrica (Fig. 17C), Ophthalmidium stuifense (Paalzow) (Fig. 14X), Planularia tricarinella (Reuss), Lenticulina ex. gr. quenstedti (Gümbel) and others. In the Peribaltic Syneclise, the upper limit of the Lenticulina russiensis-Epistomina uhligi Zone is marked by the last occurrence of most of the Oxfordian foraminifera species in the Lower Kimmeridgian (Bauhini Zone; Fig. 15).

\section{LOWER KIMMERIDGIAN}

According to the proposed stratigraphic scheme (after Wierzbowski et al., 2016), the Lower Kimmeridgian includes sedimentary series that were previously assigned to the Upper Oxfordian, comprising most of the Bimammatum Zone (excluding the Hypselum Zone) and the Planula Zone. The position of the Oxfordian/Kimmeridgian boundary between the Hypselum and Bimammatum zones has been proved based on ammonite fauna in northeastern Poland and the Peribaltic Syneclise (Wierzbowski et al., 2015), as well as in the Wielun Upland of central Poland (Wierzbowski et al., 2016). In the deposits that were previously assigned to the Upper Oxfordian, a species characteristic for the Lower Kimmeridgian appears (Bielecka and Pożaryski, 1954; Bielecka and Styk, 1964, 1966, 1968). The appearance of Kimmeridgian species in the Planula Zone was reported in a paper on the Wielun Upland (Garbowska, 1970) and in a microfaunal report on the Holy Cross region (Barwicz-Piskorz, 1995). Kimmeridgian foraminifera have also been found in deposits assigned to the Upper Oxfordian (based on lithological and geophysical data) in the recently analyzed deep boreholes of the Polish Lowlands (Smoleń and Bielecka 2008; Smoleń, 2011d, 2012c, 2014c, 2015). According to the latest micropalaeontological studies carried out in the Peribaltic Syneclise and based on correlation with ammonite zones, foraminiferal assemblages typical of the Lower Kimmeridgian appear in the Subboreal Baylei Zone correlated in that area with the Submediterranean Bimammatum Zone and the Boreal Bauhini Zone (Smoleń, 2008c; Smoleń and Wierzbowski, 2012, 2015).

In the Lower Kimmeridgian, like in the Oxfordian, there is a taxonomic diversity within the foraminiferal assemblages depending on the facies type and influences of the individual palaeogeographic provinces. Therefore, this report provides two charts of age ranges of stratigraphically important foraminiferal species representative of carbonate facies (Fig. 18) and typical of the Łyna Formation in northeastern Poland (Fig. 19). The greatest taxonomic diversity of the foraminiferal fauna is observed between the area of northeastern Poland (Peribaltic Syneclise), where the Lower Kimmeridgian deposits are represented by muddy-clayey-marly facies of the Łyna Formation, and the remaining areas of the Polish Lowlands dominated by various types of carbonates. In the Lower Kimmeridgian, the epicontinental marine basin of the Polish Lowlands remained under the influence of the Submediterranean Province. However, in NE Poland (Peribaltic Syneclise) there is a strong influence of the Subboreal Province. This had an impact on the nature of the microfauna, which was marked by the presence, in this part of the Polish Lowlands, of mixed foraminiferal associations.

\section{FORAMINIFERAL ASSEMBLAGES: CENTRAL, EASTERN} AND PART OF NORTHERN POLAND

The Lower Kimmeridgian deposits of central, eastern and part of northern Poland are composed of carbonates represented by various types of limestones: oolithic limestone - Brda Formation, marly limestones - Calcareous-Marly-Coquina Formation, and marls - Pałuki Formation (see Niemczycka, 1997).

Within these deposits, a regional diversity of foraminiferal assemblages is observed. Larger associations with respect to the number of both individuals and taxa are found in marly facies. In contrast, the compact limestones and oolitic limestones show significant depletion in foraminiferal abundance. Deposits of the Bimammatum Zone (after Wierzbowski at al., 2016) have yielded scarce foraminifers. Foraminiferal assemblages in these deposits do not contain characteristic species but long-ranging taxa known predominantly from Oxfordian deposits. Larger foraminiferal assemblages associated with carbonate facies appear in the Planula Zone (Fig. 18). Apart from species known from older deposits, they contain a number of new taxa with stratigraphic distributions ranging into the upper series of the Lower Kimmeridgian. In the Planula Zone, the characteristic species include: Haplophragmoides canui Cushman (Fig. 17U), Alveosepta jaccardi (Schrodt) (Fig. 17O), Pseudolamarckina obliquicamerata Dulub (Fig. 17P1, P2), Qinqueloculina jurassica Bielecka et Styk (Fig. 17J), Trocholina solecensis Bielecka et Pożaryski, Paleogaudryina varsoviensis (Bielecka et Pożaryski), Saracenaria cornucopiae (Schwager) (Fig. 17F, G), Spirillina infima (Strickland), Marginulinopsis buskensis (Bielecka et Pożaryski) (Fig. 17Y, Z), Tristix suprajurassica (Paalzow) and Eoguttulina inovroclaviensis (Bielecka et Pożaryski). Marly facies often contain agglutinated foraminifers of the genus Ammobaculites: A. infrajurensisis (Terquem) (Fig. 17H), A. coprolithiformis (Terquem) (Fig. 17I) and $A$. brausteini Cushman et Appland. Starting from the Platynota Zone, and then in the Hypselocyclum and Divisum zones, foraminiferal assemblages become richer of both taxa and individuals. In the upper Lower Kimmeridgian carbonates of central and eastern Poland (Calcareous-Marly-Coquina Formation) and in deposits of northwestern and partly northern area of the Polish Lowlands (Brda Formation; see Niemczycka, 1997), the most frequent taxa include Quinqueloculina 


\begin{tabular}{|c|c|c|c|c|c|}
\hline \multicolumn{5}{|c|}{ KIMMERIDGIAN } & STAGES \\
\hline \multicolumn{5}{|c|}{ LOWER } & S U B STAGES \\
\hline 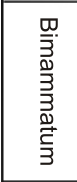 & $\begin{array}{l}\frac{\partial}{N} \\
\frac{\vec{c}}{\partial}\end{array}$ & $\begin{array}{l}\frac{0}{0} \\
\stackrel{0}{3} \\
\frac{0}{\Delta} \\
\frac{0}{0}\end{array}$ & 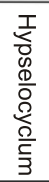 & $\begin{array}{l}\frac{0}{5} \\
\frac{5}{2} \\
\frac{5}{3}\end{array}$ & $\begin{array}{c}\text { Standard ammonite } \\
\text { zonation }\end{array}$ \\
\hline $\begin{array}{l}k-- \\
k-- \\
k-- \\
k-- \\
k-- \\
k-- \\
k-- \\
k-- \\
k-- \\
k-- \\
k-- \\
k-- \\
k-- \\
k-- \\
k-- \\
k-- \\
k-- \\
k-- \\
k-- \\
k--\end{array}$ & $\begin{array}{l}-- \\
-- \\
-- \\
--- \\
-- \\
-- \\
-- \\
-- \\
-- \\
-- \\
-- \\
-- \\
-- \\
--- \\
--- \\
-- \\
-- \\
-- \\
--\end{array}$ & $\begin{array}{l} \\
- \\
-- \\
-- \\
-- \\
-- \\
-- \\
--- \\
--- \\
--- \\
--- \\
---\end{array}$ & $\begin{array}{r} \\
\\
\\
\\
\\
\\
-1 \\
- \\
- \\
- \\
-\end{array}$ & & 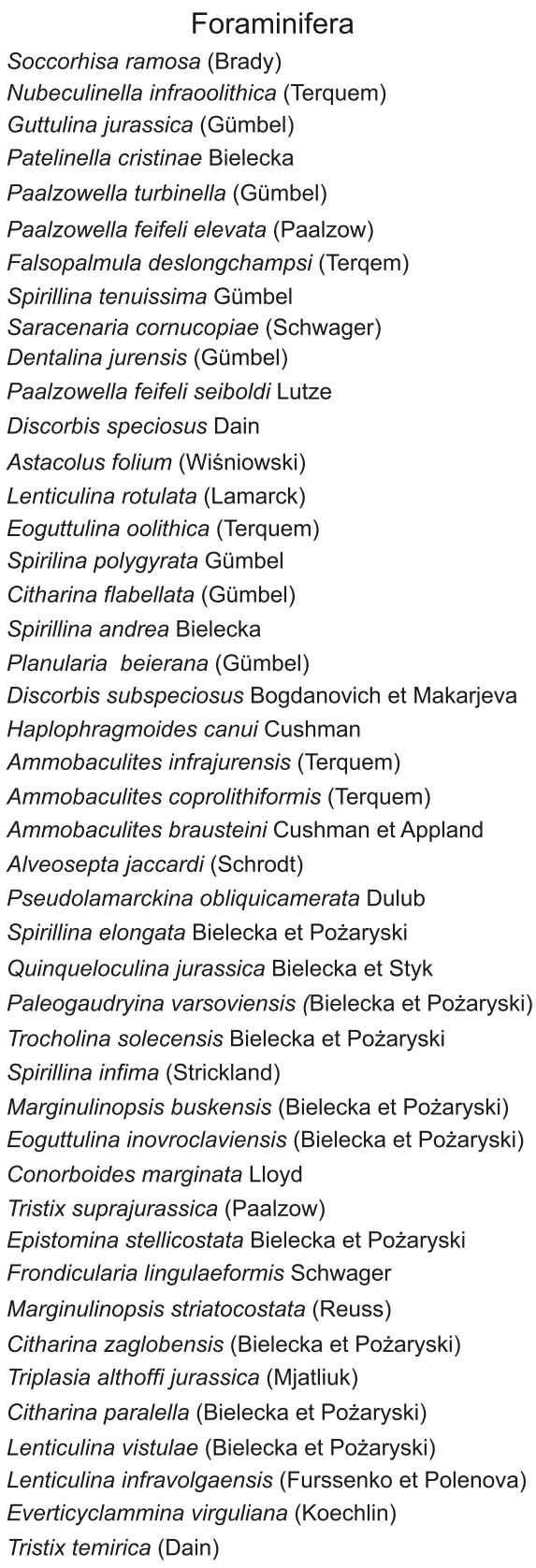 \\
\hline
\end{tabular}

Fig. 18. Stratigraphic range charts of foraminifera species from the Lower Kimmeridgian deposits of the Polish Lowlands (central, eastern and part of northern Poland), the Submediterranean standard ammonite zonation as used by Wierzbowski et al. (2014) 


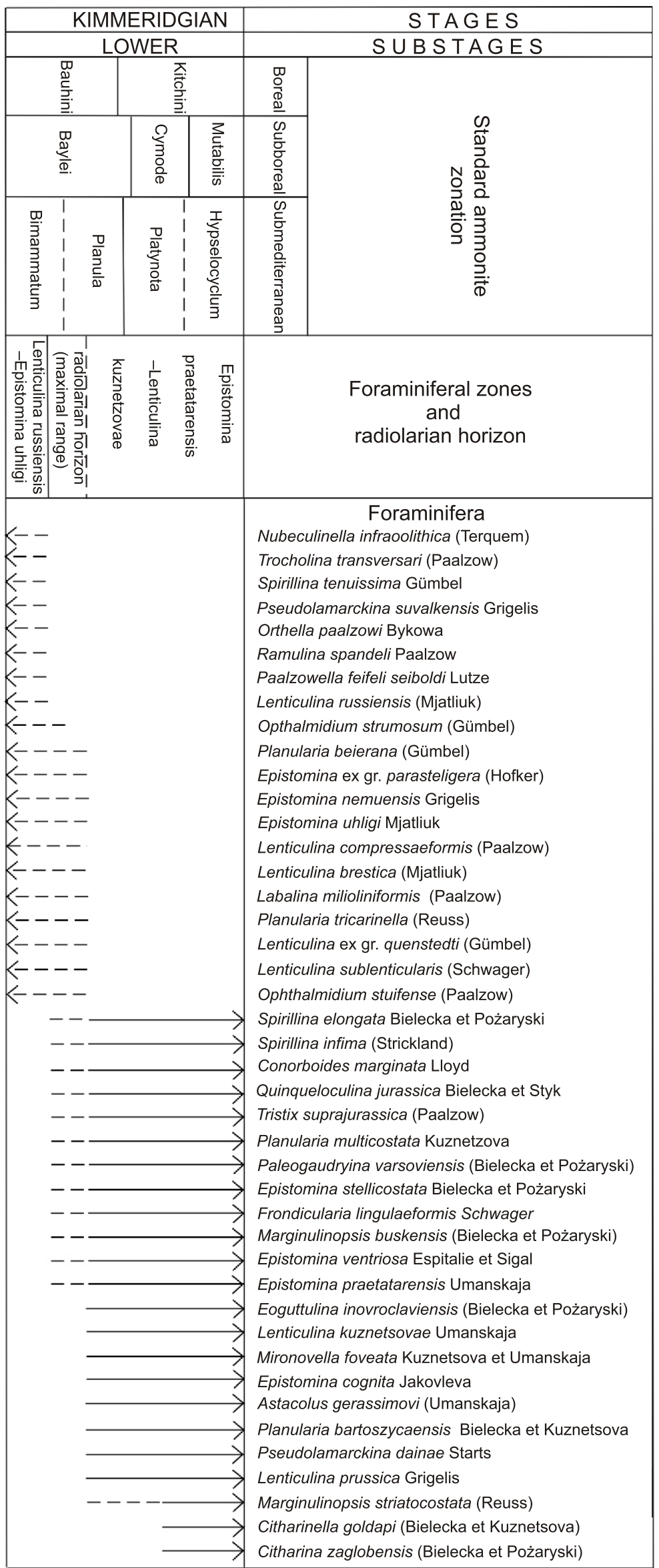

Fig. 19. Stratigraphic range charts of foraminifera species from the Lower Kimmeridgian deposits of the Polish Lowlands ( $\mathrm{N}$ and NE Poland), correlation of the Boreal and Subboreal ammonite zonations with the Submediterranean zonation as proposed by Wierzbowski et al. (2014, 2015, 2016) 
jurassica Bielecka et Styk, Trocholina solecensis Bielecka et Pożaryski, Paleogaudryina varsoviensis (Bielecka et Pożaryski), Spirillina infima (Strickland), Frondicularia lingulaeformis Schwager, Marginulinopsis buskensis (Bielecka et Pożaryski), Tristix suprajurassica (Paalzow), Eoguttulina inovroclaviensis (Bielecka et Pożaryski) (Fig. 17L), E. stellicostata Bielecka et Pożaryski, Spirillina elongata Bielecka et Pożaryski, Conorboides marginata Llyod, Marginulinopsis striatocostata (Reuss) (Fig. 17Aa), Citharina zaglobensis (Bielecka et Pożaryski) (Fig. 17W, X), C. paralella (Bielecka et Pożaryski) (Fig. 20A) and Triplasia althoffi jurassica (Mjatliuk) (Fig. 17M, N). Besides these characteristic species, the Lower Kimmeridgian of central, eastern, northwestern and partly northern Poland contains cosmopolitan species with long age ranges. The most common taxa are Astacolus varians (Bornemann), A. folium (Wiśniowski), Lenticulina brueckmanni (Mjatliuk), L. subalata (Reuss), L. prima (d Orbigny), Planularia tricarinella (Reuss), Eoguttulina oolithica (Terquem), and others. At the end of the Lower Kimmeridgian (Divisum Zone), a few new species have their first occurrences, e.g. Lenticulina vistulae (Bielecka et Pożaryski) (Fig. 20L), L. infravolgaensis (Fuessenko et Polenova) (Fig. 20M), Everticyclammina virguliana (Koechlin) (Fig. 20G) and Tristix temirica (Dain) (Fig. 20F).

\section{FORAMINIFERAL ASSEMBLAGES: NORTHEASTERN POLAND (PERIBALTIC SYNECLISE)}

The Early Kimmeridgian of NE Poland (Peribaltic Syneclise), like the Oxfordian, was a time of terrigenous-calcareous deposition of the Łyna Formation (see Niemczycka, 1997). The deposits contain foraminiferal assemblages different from those in other areas of the Polish Lowlands.

In the Peribaltic Syneclise, the Oxfordian Lenticulina russiensis-Epistomina uhligi foraminiferal Zone (Grigelis, 1982) terminates its stratigraphic age in the lowermost Lower Kimmeridgian. Upper boundary of this zone correlates with the lowermost part of the Bauhini Zone and the Baylei Zone (Smoleń and Wierzbowski 2012; Fig.19).

Deposits of the Lenticulina russiensis-Epistomina uhligi Zone are overlain by a level with radiolarians ("radiolarian horizon") and depleted foraminiferal assemblages. It contains single Kimmeridgian foraminifera species, including Trocholina solecensis Bielecka et Pożaryski (Fig. 17R1, R2), Spirillina infima (Strickland) (Fig. 17S), Conorboides marginata Lloyd (Fig. 17T1, T2), Quinqueloculina jurassica Bielecka et Styk, Tristix suprajurassica (Paalzow) (Fig. 17Bb), Planularia multicostata Kuznetzova (Fig. 20C, D), Paleogaudryina varsoviensis Bielecka et Pożaryski (Fig. 17K), Epistomina stellicostata Bielecka et Pożaryski (Fig. 17Q1, Q2), E. praetatariensis Umanskaja (Fig. 20N1, N2) and E. ventriosa Espitalie et Sigal. Foraminiferal assemblages of the upper Lower Kimmeridgian are much richer in both species and individuals. Taxonomic analysis of these assemblages has allowed distinguishing the Epistomina praetatarensis-Lenticulina kuznetsovae Zone (Grigelis, 1982; Fig. 19), established earlier in the remaining areas of the Peribaltic Syneclise in the European part of Russia and in Lithuania (e.g., Grigelis, 1982, 1985; Mesezhnikov et al., 1989; Ustinova, 2012). In view of the ammonite stratigraphy revision carried out recently for the Peribaltic Syneclise in northeastern Poland (Wierzbowski et al.,
2015), the Epistomina praetatariensis-Lenticulina kuznetsovae zone corresponds to the Bauhini Zone (except its basal part) to the Kitchini Zone of the Lower Kimmeridgian. Because of the presence of ammonite faunas from various palaeogeographic provinces in the Peribaltic Syneclise, the Boreal Bauchini Zone is correlated here with the Sub-Boreal Baylei Zone and with the Sub-Mediterranean zones of Bimmamatum and Planula. The Boreal Kitchini Zone corresponds to the Subboreal zones of Cymodoce and Mutabilis and to the Submediterranean zones of Platynota and Hypselocyclum (Fig. 19). The lower part of the Epistomina praetatariensis-Lenticulina kuznetsovae foraminiferal zone, which corresponds possibly to the radiolarian horizon, has a poor assemblage of foraminifers and is difficult for unequivocal interpretation.

In the Epistomina praetatariensis-Lenticulina kuznetsovae Zone, the most common species (including those indicative of the zone) show a Boreal-Atlantic character, among others: Epistomina praetatariensis Umanskaja, E. ventriosa Espitalie et Sigal, E. cognita Jakovleva (Fig. 200), Lenticulina kuznetsovae Umanskaja (Fig. 20H, I), L. prussica Grigelis (Fig. 20J, K), Mironovella foveata Kuznetsova et Umanskaja (Fig. 20P), Planularia multicostata Kuznetzova, Atacolus gerassimovi (Umanskaja), Planularia bartoszycaensis Bielecka et Kuznetsova (Fig. 20E), Pseudolamarckina dainae Startseva (Fig. 20R) and Citharinella goldapi (Bielecka et Kuznetzova) (Fig. 20B). However, there are also other characteristic species, e.g. Frondicularia lingulaeformis Schwager, Quinqueloculina jurassica Bielecka et Styk, Tristix suprajurassica (Paalzow), Planularia beierana (Terquem), Spirillina elongata Bielecka et Pożaryski, Conorboides marginata Llyod, Marginulinopsis striatocostata (Reuss), Trocholina solecensis Bielecka et Pożaryski, Paleogaudryina varsoviensis Bielecka et Pożaryski, Epistomina stellicostata Bielecka et Pożaryski, and others having southern affinities. The character of the faunas described strongly suggests that, during Early Kimmeridgian time, the Peribaltic Syneclise constituted the main marine connection between the Boreal and Submediterranean seas of Europe.

\section{CONCLUSIONS}

This article provides a biostratigraphic approach to data on the most important foraminifera species found in Middle and Upper Jurassic (Oxfordian and Lower Kimmeridgian) deposits of extra-Carpathian Poland.

1. The proposed scheme of ranges of index foraminifera species is presented in relation to the currently used standard ammonite zonations.

2. Based on the detail study of foraminifers in the Oxfordian and Lower Kimmeridgian deposits, the different foraminiferal assemblages were distinguished with reference to the lithofacies in the individual parts of the Polish Basin and varying influences of the palaeogeographical provinces (characteristic of carbonates of the so-called Sponge Megafacies, and of the Łyna Formation clastic deposits).

3. Additionally, based on the vertical succession of foraminiferal species found in Oxfordian and Lower Kimmeridgian deposits of the Łyna Formation in NE Poland, the foraminiferal zones of Ophthalmidium sagittum Epistomina volgensis, Ophthalmidium strumosum-Lenticulina brestica, and Lenticulina russiensis-Epistomina uhligi and Epistomina 


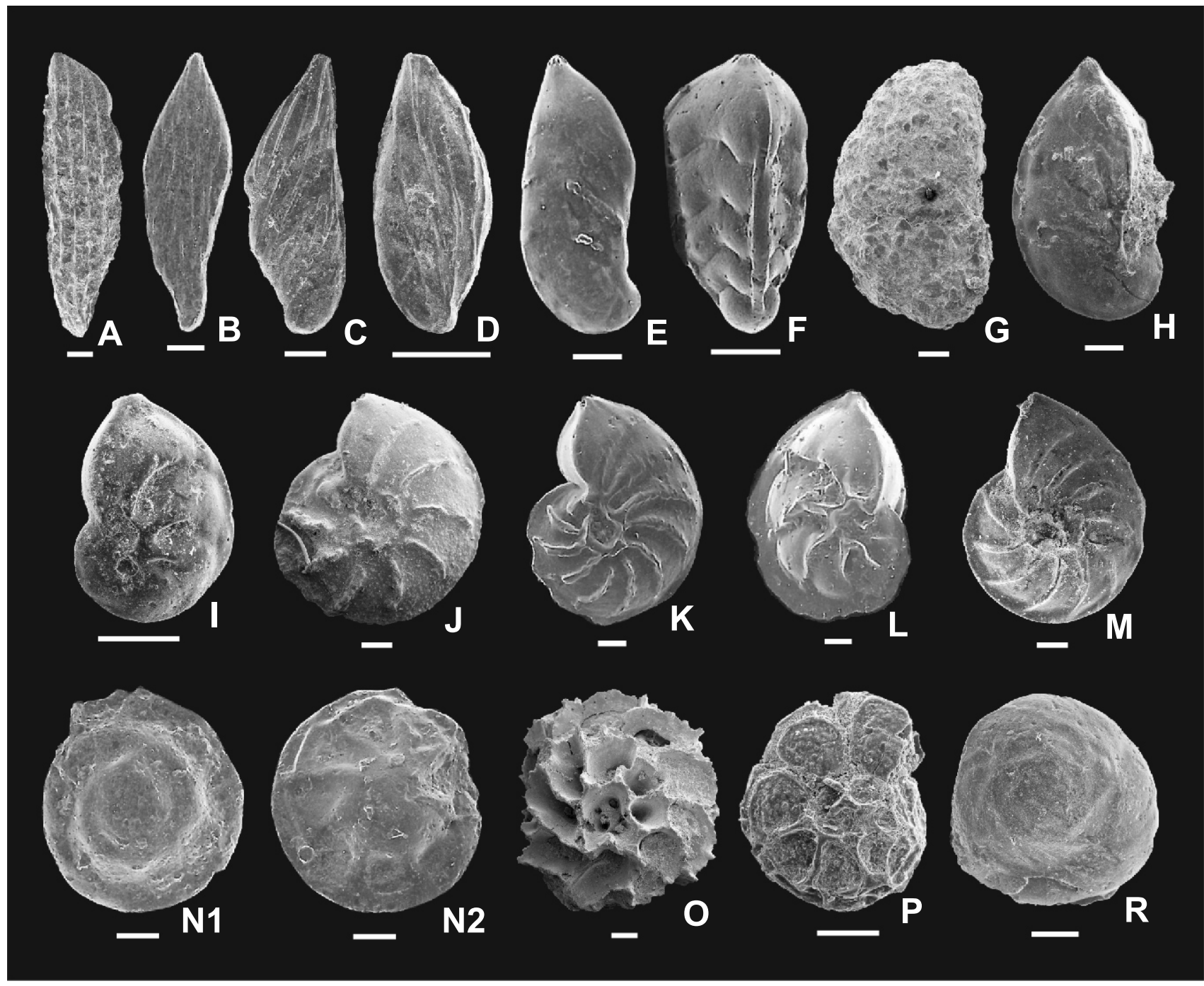

Fig. 20. Foraminifers from Lower Kimmeridgian carbonates of the Polish Lowlands (A, F, G, L, M) and Lower Kimmeridgian marly deposits of the Kyna Formation (Epistomina praetatariensis-Lenticulina kuznetsovae Zone) of NE Poland (B-E, H-K, N1-R)

A - Citharina paralella (collection of Smoleń, 2015); B - Citharinella goldapi (collection of Smoleń, 2015); C, D - Planularia multicostata (collection of Smoleń, 2015); E - Planularia bartoszycaensis (collection of Smoleń, 2015); F - Tristix temirica (collection of Smoleń, 2015); G Everticyclammina virguliana (collection of Bielecka and Styk, 1980); H, I - Lenticulina kuznetsovae (collection of Smoleń, 2015); J, K Lenticulina prussica (collection of Smoleń, 2015); L - Lenticulina vistulae (collection of Smoleń, 2015); M - Lenticulina infravolgaensis (collection of Smoleń, 2015); N1 - Epistomina praetatarensis, dorsal side (collection of Smoleń, 2015); N2 - Epistomina praetatarensis, ventral side (collection of Smoleń, 2015); O - Epistomina cognita (collection of Smoleń, 2015); P - Mironovella foveata (collection of Smoleń, 2015); $\mathbf{R}$ - Pseudolamarckina dainae (collection of Smoleń, 2015); scale bars - $100 \mu \mathrm{m}$

praetatarensis-Lenticulina kuznetzovae are characterized following the original authors' descriptions.

Acknowledgements. The study was financed by the Polish Geological Institute - National Research Institute (grant no. 61.2308.1601.00.0). The authors are thankful to Prof.
A. Wierzbowski for comments and suggestions on ammonite biostratigraphy. We would like to thank the reviewers: A.M. Ustinova and, in particular, Anonymous one. Editor-in-chief of Geological Quarterly T. Peryt is acknowledged for helpful comments that contributed to the final version of article.

\section{REFERENCES}

Azbel, A.Y., Grigelis, A.,A., Kuznetsova, K.I., 1991. Jurassic System. Upper Series. European Part of the USSR (in Russian). Practical guide to microfauna of the USSR, Mesozoic foraminifers, 5: 64-76. Nedra, Leningrad.
Barski, M., Dembicz, K., Praszkier, T., 2004. Biostratigraphy and the Mid-Jurassic environment from the Ogrodzieniec quarry. Tomy Jurajskie, 2: 61-68. 
Barwicz-Piskorz, W., 1995. Foraminiferal assemblages and stratigraphy of Upper Jurassic in Holy Cross Mountains district (in Polish with English summary). Rozprawy i Monografie, 21: $1-147$.

Basov, B.A., 1974. O nekotorykh ossobiennostyakh geograficheskogo razprostroneniya foraminifer $v$ yurskom periode (in Russian). Trudy Instituta Geologii i Geofiziki Sibirskogo Otd. Akademii Nauk SSSR, 80: 16-63.

Bielecka, W., 1956. Investigation of the Lower Malm in the vicinity of Trzebnia (Upper Silesia) (in Polish with English summary). Biuletyn Instytutu Geologicznego, 102: 60-80.

Bielecka, W., 1960a. Micropaleontological stratigraphy of the Lower Malm in the vicinity of Chrzanów (Southern Poland) (in Polish with English summary). Prace Instytutu Geologicznego, 31: 1-155.

Bielecka, W., 1960b. Micropaleontological stratigraphy of the Upper Jurassic sediments of Poland excluding the Carpathians (in Polish with English summary). Kwartalnik Geologiczny, 4 (4): 949-962.

Bielecka, W., 1961. Microfauna of Jurassic sediments in Wojszyce region (in Polish with English summary). Kwartalnik Geologiczny, 5 (4): 869-881.

Bielecka, W., 1964. Result of micropaleontological investigations (Jurassic) (in Polish with English summary). Biuletyn Instytutu Geologicznego, 176: 85-88.

Bielecka, W., 1965. Callovian of the north-western area of Poland in the light of connections of microfauna with facies (in Polish with English summary). Kwartalnik Geologiczny, 9 (2): 281-288.

Bielecka, W., 1973. Mikrofauna osadów jurajskich (in Polish). Profile Głębokich Otworów Wiertniczych Instytutu Geologicznego, 9: 125-131.

Bielecka, W., 1974. Wyniki badań mikrofaunistycznych jury środkowej i górnej (in Polish). Profile Głębokich Otworów Wiertniczych Instytutu Geologicznego, 14: 171-182.

Bielecka, W., 1980. Jura górna. Rząd Foraminiferida (in Polish). In: Budowa Geologiczna Polski, 3. Atlas skamieniałości przewodnich i charakterystycznych. Część 2 b. Mezozoik. Jura (ed. L. Malinowska): 291-325. Wyd. Geol., Warszawa.

Bielecka, W., Dąbrowska, Z., 1958. Stratigraphy of the Malm in the area of Kamień Pomorski in Western Pomerania (in Polish with English summary). Biuletyn Instytutu Geologicznego, 142: $1-72$.

Bielecka, W., Pożaryski, W., 1954. Micropaleontological stratigraphy of the upper Malm in central Poland (in Polish with English summary). Prace Instytutu Geologicznego, 12: 1-77.

Bielecka, W., Styk, O., 1964. Micropaleontological Upper Jurassic stratigraphy in the Kcynia I, II and IV bore-holes (in Polish with English summary). Biuletyn Instytutu Geologicznego, 175: 129-135.

Bielecka, W., Styk, O., 1966. The Malm microfauna in the southern part of the Peri-Baltic Syneclise (in Polish with English summary). Kwartalnik Geologiczny, 10 (2): 350-367.

Bielecka, W., Styk, O., 1968. Distribution of Oxfordian and Kimmeridgian microfauna assemblages in the Lowland area of Poland, depending upon facial differences (in Polish with English summary). Kwartalnik Geologiczny, 12 (2): 324-344.

Bielecka, W., Styk, O., 1969a. Some stratigraphically important Kujawian and Bathonian foraminifera of Polish Lowland. Rocznik Polskiego Towarzystwa Geologicznego, 31: 515-531.

Bielecka, W., Styk, O., 1969b. Assemblage of foraminifers and ostracods in the deposits of clay-siltstone-arenaceous facies of Kujavian and Bathonian age within the Polish Lowland area (in Polish with English summary). Kwartalnik Geologiczny, 13 (3): 619-628.

Bielecka, W., Styk, O., 1981a. Foraminifer biostratigraphy of the Aalenian and Bajocian in Kujawy (in Polish with English summary). Kwartalnik Geologiczny, 25 (4): 651-673.

Bielecka, W., Styk, O., 1981b. Biostratigraphy of the Bathonian and Callovian deposits of North-Western Poland based on occurrence of foraminifers and ostracods (in Polish with English summary). Prace Instytutu Geologicznego, 100: 1-156.
Bielecka, W., Styk, O., Pazdro, O., Kopik, J.,1980. Jura środkowa. Rząd Foraminiferida (in Polish). In: Budowa Geologiczna Polski, 3. Atlas skamieniałości przewodnich i charakterystycznych. Część 2 b. Mezozoik. Jura (ed. L. Malinowska): 108-135. Wyd. Geol., Warszawa.

Dayczak-Calikowska, K., 1977. The Upper Bathonian and Callovian in northwest Poland (in Polish with English summary). Prace Instytutu Geologicznego, 84.

Dayczak-Calikowka, K., 1980. Jura środkowa. Korelacja biostratygraficzna jury środkowej Polski z innymi obszarami (in Polish). In: Budowa Geologiczna Polski, 3. Atlas skamieniałości przewodnich i charakterystycznych. Część 2 b. Mezozoik. Jura (ed. L. Malinowska): 101-108). Wyd. Geol., Warszawa.

Dayczak-Calikowka, K., 1997. The Middle Jurassic. Sedimentation, paleogeography and paleotectonics (in Polish with English summary). Prace Państwowego Instytutu Geologicznego, 153: 269-283.

Dayczak-Calikowka, K., Kopik, J., 1973. Jura środkowa (in Polish). In: Budowa Geologiczna Polski, 1, cz. 2 (ed. S. Sokołowski): 141-471 Wyd. Geol., Warszawa.

Dayczak-Calikowka, K., Marcinkiewicz, T., 1997. The Middle Jurassic. Biostratigraphy (in Polish with English summary). Prace Państwowego Instytutu Geologicznego, 153: 250-263.

Dembicz, K., Głowniak, E., Matyja, B.A., Praszkier, T., 2006. Stop B1.4, Ogrodzieniec Quarry, uppermost Bathonian to Middle Oxfordian ammonite succession. In: Jurassic of Poland and adjacent Slovakian Carpathians (eds. A. Wierzbowski \& al.): 144-148. Field trip guidebook of 7 th International Congress on the Jurassic System. Polish Geological Institute, Warszawa.

Dembowska, J., 1964. Results obtained in four bore-holes in the vicinity of Kcynia (in the Kujawy region) (in Polish with English summary). Biuletyn Instytutu Geologicznego, 175: 7-129.

Feldman-Olszewska, A., 1997. Depositional architecture of the Polish epicontinental Middle Jurassic basin. Geological Quarterly, 41 (4): 491-508.

Garbowska, J., 1970. Foraminiferal assemblages of the uppermost Oxfordian and Lower Kimmeridgian of the Wieluń Upland and their stratigraphic importance (in Polish with English summary). Acta Geologica Polonica, 20: 33-89.

Garbowska, J., Łącka, B., Pazdro, O., 1978. Interrelation between microfauna and nature of Dogger deposits of the Częstochowa Jura (Poland). Acta Palaeontologica Polonica, 23: 89-105.

GedI, P., Kaim, A., 2012. An introduction to the palaeoenviromental reconstruction of the Bathonian (Middle Jurassic) ore-bearing clays at Gnaszyn, Kraków-Silesia Homocline, Poland. Acta Geologica 62: 67-280.

Głowniak E., 2002. The ammonites of the family Perisphinctidae from the Plicatilis Zone (lower Middle Oxfordian) of the Polish Jura Chain (Central Poland); their taxonomy, phylogeny and biostratigraphy. Acta Geologica Polonica, 52: 307-364.

Głowniak, E., 2006a. Correlation of the zonal schemes at the Middle-Upper Oxfordian boundary (Jurassic) in the Submediterranean Province: Poland and Switzerland. Acta Geologica Polonica, 56: 1-16.

Głowniak, E., 2006b. The Platysphinctes immigration event: biostratigraphic and paleobiogeographic implications for the Middle Oxfordian (Late Jurassic) seas of central Europe (NW Germany and Poland). Neues Jahrbuch für Geologie und Paläontologie Abhandlungen, 241: 155-201.

Głowniak, E., 2012. The perisphinctid genus Prososphinctes Schindewolf (Ammonoidea, subfamily Prososphinctinae nov.): an indicator of palaeoecological changes in the Early Oxfordian Submediterranean sea of southern Poland. Neues Jahrbuch für Geologie und Paläontologie Abhandlungen, 264: 117-179.

Grigelis, A., 1982. Biostratigrafiya verkhneyurskikh otlozheniy SSSR po foraminiferam (in Russian). Mokslas, Wilnius.

Grigelis, A., 1985. Zonalnaya stratigrafiya baltitskoy yury po foraminiferam (in Russian). Nedra, Moskwa.

Kopik, J., 1956. Stratigraphy and microfauna of the Jurassic in the "Borucice" deep bore-hole near Łęczyca (district of Łódź) (in Polish with English summary). Biuletyn Instytutu Geologicznego, 102: 31-45. 
Kopik, J., 1969. On some representatives of the family Nodosariidae (Foraminiferida) from the Middle Jurassic of Poland. Rocznik Polskiego Towarzystwa Geologicznego, 39 533-550.

Kopik, J., 1998. Lower and Middle Jurassic of the north-eastern margin of Upper Silesian Coal Basin. Biuletyn Państwowego Instytutu Geologicznego, 378: 67-131.

Kopik, J., Marcinkiewicz, T., 1997. The Middle Jurassic. The Jurassic of Poland (in Polish with English summary). Prace Państwowego Instytutu Geologicznego, 153: 236-250.

Kopik, J., Znosko, J., 1968. La limite du Bajocien et du Bathonien de même que le problème du Vésulien et du Kuyavien en Pologne (in Polish with French summary). Przegląd Geologiczny, 16: 269-273.

Leonowicz, P., 2013a. The significance of mudstone fabric combined with palaeoecological evidence in determining sedimentary processes - an example from the Middle Jurassic of southern Poland. Geological Quarterly, 57 (2): 243-260.

Leonowicz, P., 2013b. Ichnofabrics of shallow-marine mudstone, the result of changing environmental conditions: an example from the Middle Jurassic ore-bearing clay from southern Poland. Facies, 61: 1-21.

Leonowicz, P., 2015. Storm-influenced deposition and cyclicity in a shallow-marine mudstone succession - example from the Middle Jurassic ore-bearing clays of the Polish Jura (southern Poland). Geological Quarterly, 59 (2): 325-344.

Malinowska, L., 1966. Stratigaphical basis of the Lower and Middle Oxfordian in the north and north west Poland (in Polish with English summary). Kwartalnik Geologiczny, 10 (3): 786-800.

Malinowska, L., 1976. Boreal faunal influences in the Lower and Middle Oxfordian of Poland. Biuletyn Instytutu Geologicznego, 291: 5-40.

Malinowska, L., 1980. Atlas skamieniałości przewodnich charakterystycznych (in Polish). Budowa geologiczna Polski, 3 Cz. 2b: Mezozoik, Jura. Wyd. Geol., Warszawa.

Malinowska, L., 1981. The Cawtoniceras tenuiserratum Zone of the Middle Oxfordian of Poland. Biuletyn Instytutu Geologicznego, 335: $27-50$

Malinowska, L., 1987. The oldest ammonites of the genus Amoeboceras Hyatt, 1900 from Oxfordian deposits in northern and north-western Poland (in Polish with English summary). Biuletyn Instytutu Geologicznego, 354.

Malinowska, L., 1988. Atlas of guide and characteristic fossils. Geology of Poland, 3, Part 2b: Mesozoic. Jurassic. Wyd. Geol., Warszawa.

Malinowska, L., 1991a. Boreal fauna influence in Upper Oxfordian in North and Central Poland. Prace Państwowego Instytutu Geologicznego, 135: 1-27.

Malinowska, L., 1991b. Biostratigraphy of the Oxfordian sediments of the Chrzanów Jurassic . Bulletin of the Polish Academy of Sciences, Earth Sciences, 39: 343-363.

Małecki, J., 1971. Some assemblages of Foraminifera in ore-bering clays near Częstochowa (Central Poland) (in Polish with English summary). Roczniki Polskiego Towarzystwa Geologicznego, 41: 313-320.

Marek, S., Pajchlowa, M., eds., 1997. The epicontinental Permian and Mesozoic in Poland (in Polish with English summary). Prace Państwowego Instytutu Geologicznego, 153.

Matyja, B., A., Wierzbowski, A., 1994. On correlation of Submediterranean and Boreal ammonite zonations of the Mid dle and Upper Oxfordian: new data from Central Poland Geobios Mém. Spéc., 17: 351-358.

Matyja, B., A., Wierzbowski, A., 1995. Biogeographic differentiation of the Oxfordian and Early Kimmeridgian ammonite faunas of Europe, and its stratigraphical consequences. Acta Geologica Polonica, 45: 1-8.

Matyja, B.A., Wierzbowski, A., 1998. The stratigraphical and palaeogeographical importance of the Oxfordian and Lower Kimmeridgian succession in the Kcynia IG IV borehole (in Polish with English summary). Biuletyn Państwowego Instytutu Geologicznego, 382: 35-70.
Matyja, B.A., Wierzbowski, A., 2000. Ammonites and stratigraphy of the uppermost Bajocian and Lower Bathonian between Częstochowa and Wieluń, Central Poland. Acta Geologica Polonica, 50: 191-209.

Matyja, B.A., Wierzbowski, A., 2003. Biostratygrafia amonitowa formacji częstochowskich iłów rudonośnych (najwyższy bajos-górny baton) z odsłonięć w Częstochowie (in Polish). Tomy Jurajskie, 1: 3-6.

Mesezhnikov, M.S., Azbel, A.J., Kalacheva, E.D., Rotkyte, L.M., 1989. The Middle and Upper Oxfordian of the Russian Platform (in Russian). Academy of Sciences of USSR, Stratigraphical Committee Transactions, 19: 1-158.

Olszewska, B., 2014. Results of micropaleontological investigations of the Upper Jurassic, Upper Cretaceous and Miocene sediments in the Trojanowice 2 and Cianowice 2 boreholes (south-eastern part of the Kraków-Częstochowa Upland) (in Polish with English summary). Biuletyn Państwowego Instytutu Geologicznego, 459: 109-132.

Olszewska, B., Wieczorek, J., 1988. Callovian-Oxfordian Foraminifera of the Northen Tethyan shelf on example of Cracow Upland. Revue de Paleobiologie, 2: 191-196.

Niemczycka, T., 1997. Formal and informal lithostratigraphic units (in Polish with English summary). Prace Państwowego Instytutu Geologicznego, 153: 309-321.

Pazdro, O., 1954. Próby rozpoziomowania iłów rudonośnych na podstawie mikrofauny (Badania geologiczne iłów rudonośnych Jury Krakowsko-Wieluńskiej) (in Polish). Archive publication No. 4528/95 NAG PIG-PIB.

Pazdro, O., 1958. Ophthalmidium of the Vesulian and Bathonian in the neighbourhod of Częstochowa (in Polish with English summary). Biuletyn Instytutu Geologicznego, 121: 31-45.

Pazdro, O., 1959. On the stratigraphic distribution of the Miliolidae in the Middle Jurassic of Poland (in Polish with English summary). Acta Geologica Polonica, 9: 343-381.

Pazdro, O., 1960. Micropaleontological characteristic of Vesulian and Bathonian of Polish Lowland (in Polish with English summary). Kwartalnik Geologiczny, 4 (4): 936-948.

Pazdro, O., 1967. The Bathonian microfauna from the vicinity of Ogrodzieniec. Biuletyn Instytutu Geologicznego, 211: 146-166.

Pazdro, O., 1969a. Middle Jurassic Epistominidae of Poland. Studia Geologica Polonica, 27: 7-92.

Pazdro, O., 1969b. Bathonian Globigerina of Poland. Rocznik Polskiego Towarzystwa Geologicznego, 39: 42-56.

Różycki, S.Z., 1953. Górny dogger i dolny malm Jury Krakowsko-Częstochowskiej (in Polish). Prace Instytutu Geologicznego, 17: 1-412.

Siewniak, J., 1962. Stratigraphy and microfauna of the Lower Malm in the Olkusz-Klucze region (in Polish with English summary). Kwartalnik Geologiczny, 6 (2): 325-336.

Smoleń, J., 1998. Oxfordian microfauna in the north-eastern margin of the Upper Silesian Coal Basin (in Polish with English summary). Biuletyn Państwowego Instytutu Geologicznego, 378: 207-218.

Smoleń, J., 2000. Foraminiferal stratigraphy of the Middle and Upper Jurassic boundary in Peribaltic Syneclise (NE Poland) (in Polish with English summary). Biuletyn Państwowego Instytutu Geologicznego, 393: 53-79.

Smoleń, J., 2004. Interpretacja paleośrodowiska sedymentacj środkowojurajskich iłów rudonośnych Gnaszyna na podstawie zespołów otwornic (in Polish). In: XIX Konferencja naukowa paleobiologów i biostratygrafów PTG: „Zapis paleontologiczny jako wskaźnik paleośrodowisk”, Wrocław 16-18 września 2004 r. (ed. J. Muszer): 53-55. Materiały konferencyjne.

Smoleń, J., 2006. Palaeoenvironmental significance of the foraminiferal assemblages from the Middle Jurassic deposits of Częstochowa area. Volumina Jurassica, 4: 136-137.

Smoleń J., 2007. Jura środkowa - mikrofauna (in Polish). Profile Głębokich Otworów Wiertniczych Państwowego Instytutu Geologicznego, 117: 65-67.

Smoleń, J., 2008a. Wyniki badań mikropaleontologicznych osadów jury środkowej (in Polish). Profile Głębokich Otworów 
Wiertniczych Państwowego Instytutu Geologicznego, 125 157-161.

Smoleń, J., 2008b. Mikrofauna jury środkowej (in Polish). In: Profile Głębokich Otworów Wiertniczych Państwowego Instytutu Geologicznego, 124: 189-191.

Smoleń, J., 2008c. Mikrofauna w osadach granicznych oksfordu i kimerydu w profilu Bartoszyce IG 1 (synekliza perybałtycka) próba korelacji z poziomami amonitowymi i dinocystowymi (in Polish). Geologia AGH, 34: 210-212.

Smoleń, J., 2011a. Rekonstrukcja paleośrodowiska sedymentacji środkowojurajskich iłów rudonośnych $z$ odsłonięć w Czestochowie, w świetle badań mikropaleontologicznych, sprawozdanie $z$ realizacji zadania badawczego (in Polish). Archive publication No. 6519/2017 NAG PIG-PIB, Warszawa.

Smoleń, J., 2011b. Wyniki badań mikropaleontologicznych osadów jury środkowej (in Polish). Profile Głębokich Otworów Wiertniczych Państwowego Instytutu Geologicznego, 129: 62-63.

Smoleń, J., 2011c. Wyniki badań mikropaleontologicznych osadów jury środkowej i górnej (in Polish). Profile Głębokich Otworów Wiertniczych Państwowego Instytutu Geologicznego, 128: 116-120.

Smoleń, J., 2011d. Wyniki badań mikropaleontologicznych w osadach jury górnej (in Polish). Profile Głębokich Otworów Wiertniczych Państwowego Instytutu Geologicznego, 129: 63-67.

Smoleń, J., 2012a. Faunal dynamics of foraminiferal assemblages in the Bathonian (Middle Jurassic) ore-bearing clays at Gnaszyn, Kraków-Silesia Homocline, Poland. Acta Geologica Polonica, 62: 403-419.

Smoleń, J., 2012b. Wyniki badań mikropaleontologicznych utworów jury środkowej (in Polish). Profile Głębokich Otworów Wiertniczych Państwowego Instytutu Geologicznego, 137: 139-142.

Smoleń, J., 2012c. Wyniki badań mikropaleontologicznych utworów jury górnej (in Polish). Profile Głębokich Otworów Wiertniczych Państwowego Instytutu Geologicznego, 137: 179-180.

Smoleń, J., 2012d. Mikrofauna jury górnej (in Polish). Profile Głębokich Otworów Wiertniczych Państwowego Instytutu Geologicznego, 136: 96-97.

Smoleń, J., 2014a. Wyniki badań mikropaleontologicznych utworów jury środkowej (in Polish). Profile Głębokich Otworów Wiertniczych Państwowego Instytutu Geologicznego, 141: 218-222.

Smoleń, J., 2014b. Mikrofauna w utworach jury środkowej w otworach wiertniczych Kętrzyn IG1 i IG2 (in Polish). Profile
Głębokich Otworów Wiertniczych Państwowego Instytutu Geologicznego, 138: 128-129.

Smoleń, J., 2014c. Mikrofauna w utworach jury górnej w otworach wiertniczych Kętrzyn IG1 i IG2 (in Polish). Profile Głębokich Otworów Wiertniczych Państwowego Instytutu Geologicznego, 138: $130-131$.

Smoleń, J., 2015. Wyniki badań mikropaleontologicznych utworów jury górnej i kredy dolnej (in Polish). Profile Głębokich Otworów Wiertniczych Państwowego Instytutu Geologicznego, 143: 128-130.

Smoleń, J., Bielecka, W., 2008. Mikrofauna jury górnej (in Polish). Profile Głębokich Otworów Wiertniczych Państwowego Instytutu Geologicznego, 124: 193-195.

Smoleń, J. Wierzbowski, A., 2012. Stratigraphy of the Oxfordian and Kimmeridgian boundary in Peribaltic Syneclise (NE Poland) based on the foraminifera. In: Jurassica X. Abstracts (eds. M. Krobicki, A. Feldman-Olszewska and A. Wierzbowski): 26-28. Państwowy Instytut Geologiczny, Warszawa.

Styk, O., 1997. Jura górna. Otwornice (in Polish). Prace Państwowego Instytutu Geologicznego, 153: 300-308.

Ustinova, M.A., 2012. Foraminifers and stratigraphy of Middle Oxfordian-Lower Kimmeridgian of Kostroma Region (Mikhalenino section) (in Russian). Byulletin Moskovskogo Obshchestva Ispytateley Prirody, Otdel Geologicheskiy, 87: 43-52.

Wierzbowski, A., Matyja, B.A., 2014. Ammonite biostratigraphy in the Polish Jura sections (central Poland) as a clue for recognition of the uniform base of the Kimmeridgian Stage. Volumina Jurassica, 12: 45-98.

Wierzbowski, A., Smoleń, J., Iwańczuk, J., 2015. The Oxfordian and Lower Kimmeridgian of the Peri-Baltic Syneclise (north-eastern Poland): Stratigraphy, ammonites, microfossils (foraminifers, radiolarians), facies, and palaeogeographical implications. Neues Jahrbuch für Geologie und Paläontologie Abhandlungen, 277: 63-104.

Wierzbowski, A., Atrops, F., Grabowski, J., Hounslow, M.W., Matyja, B.A., Olóriz, F., Kevin, N. Page, K.N., Parent, H., Rogov, M.A, Schweigert, G., Villaseńor, A.B., Wierzbowski, H., Wright, J.K., 2016. Towards a consistent Oxfordian/Kimmeridgian global boundary: current state of knowledge. Volumina Jurassica, 14: 15-50.

Wiśniowski, T., 1890. Mikrofauna iłów ornatowych okolic Krakowa. Otwornice keloweju górnego w Grojcu (in Polish). Pamiętnik Akademii Umiejętności, 7. 